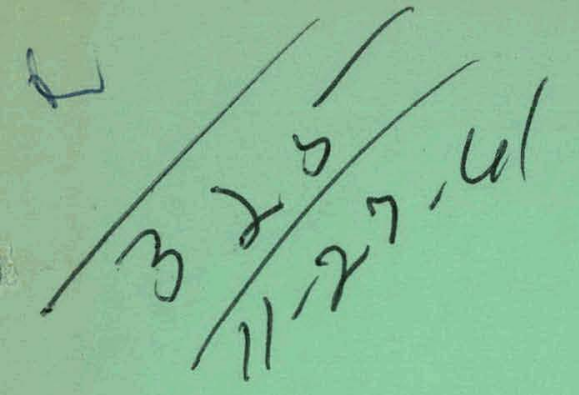

\title{
MASTER.
}

\section{MIXING AND EVAPORATION IN A PACKED VESSEL}

\section{G. K. Cederberg}

J. A. Buckham

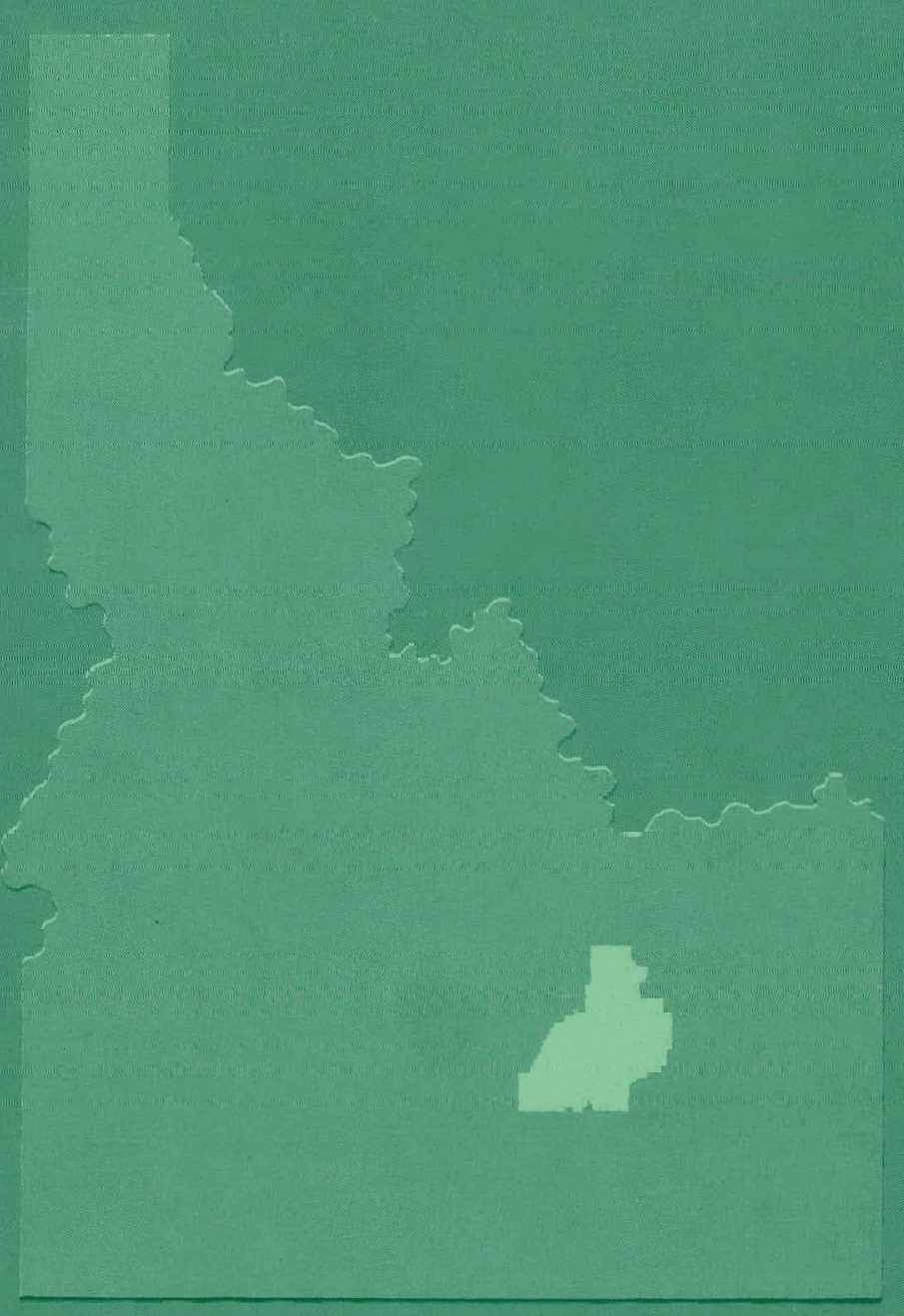

PHLLLIP PFTROLFUM COMPANY

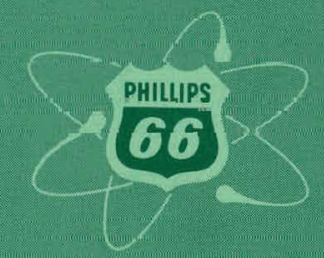

ATOMIC ENERGY DIVISION 


\section{DISCLAIMER}

This report was prepared as an account of work sponsored by an agency of the United States Government. Neither the United States Government nor any agency Thereof, nor any of their employees, makes any warranty, express or implied, or assumes any legal liability or responsibility for the accuracy, completeness, or usefulness of any information, apparatus, product, or process disclosed, or represents that its use would not infringe privately owned rights. Reference herein to any specific commercial product, process, or service by trade name, trademark, manufacturer, or otherwise does not necessarily constitute or imply its endorsement, recommendation, or favoring by the United States Government or any agency thereof. The views and opinions of authors expressed herein do not necessarily state or reflect those of the United States Government or any agency thereof. 


\section{DISCLAIMER}

Portions of this document may be illegible in electronic image products. Images are produced from the best available original document. 


\title{
PRICE $\$ .75$
}

\author{
Available from the \\ Office of Technical Services \\ U. S. Department of Commerce \\ Washington 25, D. C.
}

\section{LEGAL NOTICE}

This report was prepared as an account of Government sponsored work. Neither the United States, nor the Commission, nor any person acting on behalf of the Commission:

A. Makes any warranty or representation, express or implied, with respect to the accuracy, completeness, or usefulness of the information contained in this report, or that the usc of any information, apparatus, method, or process disclosed in this report may not infringe privately owned rights; or

B. Assumes any liabilities with respect to the use of, or for damages resulting from the use of any information, apparatus, methor, or proress disclosed in this repnrt

As used in the above, "person acting on behalf of the Commission" includes any employee or contractor of the Commission, or employee of such contractor, to the extent that such employee or contractor of the Commission, or employee of such contractor prepares, disseminates, or provides access to, any information pursuant to his employment or contract with the Commission, or his employment with such contractor. 


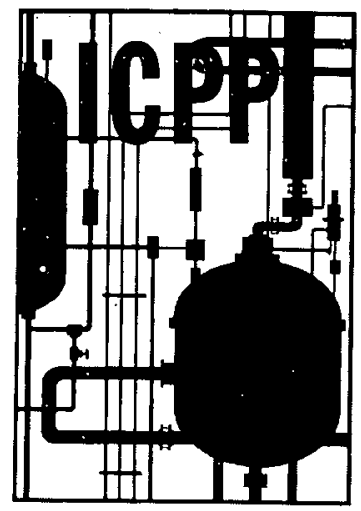

IDO-14562

AEC Research and Development Report Chemical Separations Processes for Plutonium and Uranium TID-4500 (16th Ed.)

IDAHO CHEMICAL PROCESSING PLANT

MIXING AND EVAPORATION IN A PACKED VESSEL

G. K. Cederberg

J. A. Buckham

PHILLIPS

PETROLEUM

COMPANY

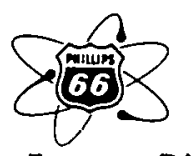

Atomic Energy Division

Contract AT(10-1).205

Idaho Operations Office

U. S. ATOMIC ENERGY COMMISSION 


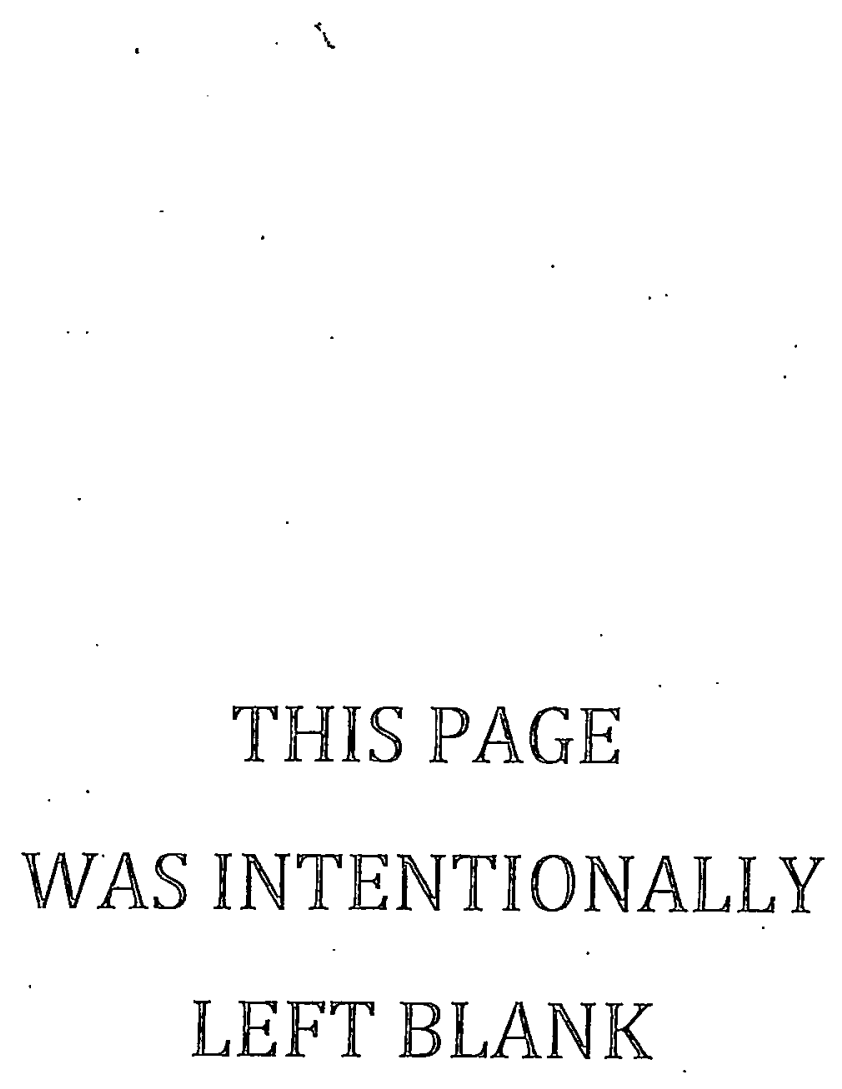


MIXING AND EVAPORATION IN A PACKED VESSEL

by

G. K. Cederberg and J. A. Buckham

$\underline{A} \underline{B} \underline{S} \underline{T} \underline{\mathrm{A}} \underline{\mathrm{C}} \underline{\mathrm{T}}$

In connection with an evaluation of the operability of a 36-inch diameter remote evaporator at the Idaho Chemical Processing Plant that was to be packed with a corrosion-resistant neutron-poison packing for criticality control, an investigation in a 30-inch diameter vessel proved that air sparging effectively mixes solutions. However, the data ' showed that at similar sparge rates the presence of the packing caused an increase in the time needed for complete mixing. The investigation also showed that solutions are readily evaporated in spite of the presence of packing in the tank. 
THIS PAGE

WAS INTENTIONALLY

LEFT BLANK 
SUMMARY . . . . . . . . . . . . . . . . . . . . . 9

INTRODUCTION . . . . . . . . . . . . . . . . . . 10

Background ...................... 10

Program Objectives . . . . . . . . . . . . . . 11

PREVIOUS WORK REVIEWED . . . . . . . . . . . . . . . . . . . 1.1

GENERAL EXPERIMENTAL CONSIDERATIONS . . . . . . . . . . . 12

Apparatus . . . . . . . . . . . . . . . . . . . . . 12

Tracer Selection and Method of Analysis . . . . . . . . I5

Data Interpretation Methods'. . . . . . . . . . . . . 15

Evaporation Test Procedures . . . . . . . . . . . . 16

DISCUSSION OF MIXING EXPERTMENTS . . . . . . . . . . . . . 16

Effect of Packing on the Mixing Times . . . . . . . . . 16

Viscosity Effects. . . . . . . . . . . . . . . . . . 19

Erfects of Air-F'low Rate and Packing on the Liquid Turbulence 20

Expansion Due to Air Holdup . . . . . . . . . . . . . 20

Effect of Liquid Level. . . . . . . . . . . . . . . 24

DISCUSSION OF MIXING INDUCED BY COMBINING LIQUIDS . . . . . . . 25

Addition of Aluminum Nitrate Solution to Water . . . . . . 25

Addition of Water to Aluminum Nitrate Solution . . . . . . 26

Mixing Induced by Instrument Air . . . . . . . . . . . 27

DISCUSSION OF EVAPORATION L'ESTS . . . . . . . . . . . . . . 27

Investigation of General Operability . . . . . . . . . 27

Evaporation Rate Studies . . . . . . . . . . . . 28

Concentration Gradient Studies . . . . . . . . . . 30

CONCLUSIONS . . . . . . . . . . . . . . . . . . . . 31

LITERATURE CTTED . . . . . . . . . . . . . . . 32 


\section{LIST OF FIGURES}

Figure

1 Photograph of the Test Vessel, Samplers, Condenser, and Instruments . . . . . . . . . . . . . . . . . . . 13

2 Photograph of Sampling Mechanism and Sample Bottle Holder 14

3 Determination of the Time Required for Complete Mixing.

for a Typical Run . . . . . . . . . . . . . . . 15

4 Effect of Packing and Sparge Air on the Time Required to Mix Cupric Nitrate into.2.2M Aluminum Nitrate and into Water . . .. . . . . . . . . . . . . . 17

5 Illustrations of Cupric Nitrate 'l'racer Addition into the Bottom of the Vessel . . . . . . . . . . . 18

6 Effect of Adding the 'Tracer into the l'op of the Vessel . 18

7 Turbulence in a Vessel Packed with 1 L/2-inch Raschilg Rings Using $3.15 \mathrm{scfm}$ of Sparge A1r per Square Foot . . . . . . 21

8 Turbulence in a Vessel Packed with 1 1/2-inch Raschig Rings Using $0.73 \mathrm{scfm}$ of Sparge Air per Square Foot . . . . . 21

9 Turbulence in a Vessel Packed with 1/2-inch Raschig Rings Using. 3.15 scfm of Sparge Air per Square. Foot . . . . . . 22

10 Turbulence in a Vessel. Packed with 1/2-inch Raschig. Rings Using 0.73 scfm of Sparge Air per Square Foot . . . . . . 22

11 Turbulence in a Vessel. Without Packing Using $3.15 \mathrm{scfm}$. of Sparge Air per Square Foot . . . . . . . . . . 23

12 Turbulence in a Vessel Without Packing Using 0.73 scfm of Sparge Air per Square Foot . . . . . . . . . . . 23

13 Effect of Air-Flow Rate on the Expansion of Liquid in a Tank Packed with 1/2-inch Raschig Rings . . . . . . . 24

14 Effect of Liquid Level on the Time Required for Complete Mixing . . . . . . . . . . . . . . . 24

15 Mixing Induced by Adding Concentrated Aluminum Nitrate on Top of Water . . . . . . . . . . . . . . . 25

16 Mixing Induced by Adding Water on Top of Concentrated Aluminum Nitrate . . . . . . . . . . . . 26

17 Over-all Heat Transfer Coefficient Using Both Jackets . . 29 


\section{LIST OF FIGURES. - cont.}

Figure

Page

18 Over-all Heat Trensfer Coefficient Using Side Jacket Alone. 29

19 Over-all Heat Transfer Coefficient Using Bottom Jacket

Alone . . . . . . . . . . . . . . . . 30

\section{LIST OF TABLES}

Table

Page

1 Typical Variations of Copper Concentration Throughout a Volume of Boiling Aluminum Nitrate Solution . . . . . . 30

2 Standard Deviation of Sample Analyses Under Various Evaporation Test Conditions . : . . . . . . . . . . . . . 31 


\section{THIS PAGE}

\section{WAS INTENTIONALLY \\ LEFT BLANK}


MIXING AND EVAPORATION IN A PACKED VESSEL

by

G. K. Cederberg and J. A. Buckham

SUMMARY

Many procedures, presently needed to control the mass or the concentration of enriched uranium in large vessels, could be improved if a permanent nuclear "poison" could be used in such vessels. Pyrex glassring packing, which contains boron, is used in some 42-inch diameter storage vessels at the Rocky Flats Plant(1) of the United States Atomic Energy Commission to give protection from a nuclear incident. The use of poison packing also appeared applicable to vessels at the Idaho Chemical Processing Plant (ICPP). However, it was necessary to test mixing and evaporation rates with a non-fissionable material in a packed vessel before a poison material, such as Pyrex rings or boron stainless steel rings, could be recommended for use at ICPP.

A 30-inch diameter jacketed tank, which was used without packing, with $1 / 2$-1nch, and with 1 1/2-inch stoneware Raschig rings, permit.ted tests to simulate plant evapuration and mixing operations. The complete mixing of the tracer into about 200 liters of water was defined as the situation when the average concentration, indicated by 4 to 6 sample points, approached within 0.8 per cent of the calculated concentration of the homogeneous solution.

More time was required for the mixing of solutions in a tank packed with either 1 1/2-inch or 1/2-inch Raschig rings than was required for mixing solution in a tank with no packing. For example, at an air-sparge rate of 3.15 scfm per square foot of tank cross section in a tank containing about 36 inches of water $3 / 4$ minule of sparging mixed the liquid in the unpacked tank, $31 / 2$ minutes of sparging mixed the solution surrounding the $11 / 2$-inch Raschig rings, and 100 minutes of sparging mixed the solution surrounding the $1 / 2$-inch Raschig rings.

In another group of tests, the addition of a dense solution, $2.2 \mathrm{M}$ aluminum nitrate $\left(\rho=1.32 \mathrm{~g} / \mathrm{cm}^{3}\right)$, to water through a $1 / 2$-inch nozzle in the top of the tank without air sparging caused relatively complete mixing in a packed tank as well as in an unpacked tank. However, the addition of water to a dense solution, such as $2.2 \mathrm{M}$ aluminum nitrate $\left(\rho=1.32 \mathrm{~g} / \mathrm{cm}^{3}\right)$, from a nozzle in the top of the tank produced very little mixing with the original solution in the tank in either the packed or the unpacked condition.

The data dealing with no packing in the tank are independently useful since they show how rapidly solutions in other similar, unpacked vessels at the ICPP can be agitated by air sparging.

The evaporation tests showed that a packed evaporator w1ll operate satisfactorily and without significant concentration gradients. Boilovers 
which can appear more frequently with packing in the tank, were prevented by several precautions during operation. Statistical analyses of the evaporation-rate data for the many combinations of side and bottom jackets, of steam pressure in the jackets, and of solution type showed that the packing did not affect the heat transfer rates for the side jacket alone and for the side and bottom jackets together. However, the data obtained using the bottom jacket alone showed that the heat transfer coefficients that prevailed at the bottom surface in the packed tank were lower than those in the unpacked tank.

In brief, these investigations. showed that if packing is used in plant vessels, the solutions in them can be mixed by air sparging and readily evaporated by boiling. The size of the packing and the air sparge rates naturally affect the operations, but not extremely.

\section{INITRODUCTTON}

\section{Background}

Experience of the United States Atomic Energy Comission's contraclurs with enriched uranium has establiehed that even concentrated solutions of this fissionable material can be processed safely if small-diameter, geometrically-safe vessels are used or if the mass and concentration of uranium in large vessels are controlled by strict adherence to operating procedures. The Idaho Chemical Processing Plant (ICPP), as constructed, employs a combination of geometrical control, using small-diameter vessels, and concentration control, using dilute uranium solutions in vessels larger than 5 inches in diameter. The latter method reduced equipment investment but introduced an element of hazard die to the fallibility of humans and instruments in spite of stringent operating procedures.

A completely reliable method of preventing a nuclear incident in a large vessel is needed, and such a method should allow storage of any mass of uranium up to a saturated solution. One promising method, requiring a minimum of procedures, is to distribute a corrosion-resistant, neutronpoison material within the appropriate large vessels.

Bldinger, Schuske, and Smith(1) of the Dow Chemical Company at the Rocky Flats Plant of the United States Atomic Energy Commission near Denver, Colorado, explored the possibility of using permanent poisors and performed neutron-multiplication experiments in a 42-inch diameter tank packed with 1 1/2-inch, Pyrex-glass Raschig rings. These rings contained 1.2 .5 weight per cent of boron oxide and occupied about 18 per cent of the vessel volume. They found thal solutione with up to at least, 430 grams of enriched uranium per liter would be critically safe in a vessel which was surrounded on three sides by concrete-block walls, 16 inches thick, and on the fourth side by an existing building woll. Based on these findings, Pyrex glass rings are used in many large-diameter vessels at the Rocky Flats plant to provide criticality control.

This same method is undoubtedly applicable to ICPP vessels. However, Pyrex glass rings would probably not be satisfactory because they might suffer excessive breakage if dumped into existing vessels and because the 
boron might be leached from the rings by many of the process and decontamination solutions. Raschig rings and parallel-plate cartridges made of boron stainless steel have been suggested for ICPP use.

Program Objectives

One ICPP uranium-salvage batch evaporator has long been a bottleneck because its use has been encumbered with many criticality safeguard procedures. It was proposed that this evaporator, 36 inches in diameter, be modified with boron stainless steel Raschig-ring packing to eliminate some of the safeguard procedures while still making it safe for any uranium concentration. However, it was not known if Raschig rings in a 36-inch diameter tank would confine the salts in specific regions of the packing during evaporation or if the contents of the tank could be readily mixed with compressed air from a sparge ring in the bottom of the tank.

A program of experiments was proposed (using stoneware Raschig rings instead of boron stainless steel rings) to investigate the heat transfer characteristics of a packed evaporator and the solute concentration variations in the packing during normal evaporation. It was also proposed to investigate the effect of both $1 / 2$-inch and. 1 1/2-1nch Raschig ring packlngs on the mixing of liquids as a function of air-flow rates, solution properties, and liquid level.

Mixing induced by the combination of solutions of dissimilar densities without air sparging was also to be investigated. These tests were expected to indicate the solute concentration gradients that could exist in either packed or unpacked tanks if concentrated uranyl nitrate solutions were unintentionally mixed with dilute solutions.

\section{PREVIOUS WORK REVIEWED}

The technical abstracts and indices were thoroughly searched for artililes on either the air-sparge mixing or the evaporation of solutions in a tank packed with Raschig rings. No references were found on the use of Raschig rings or any other packing in either mixing or evaporation studies. Many articles $(3,4,7,9,11,13)$ on the formation and rise of air bubbles in liquid indicated the physical properties and the geometry of the system could influence the mixing rate. Only one article(8) was found on the air-sparge mixing of liquids in a tank without packing.

Datta, Napier, and Newitt(3) summarized most of the previous investigations on the influence of viscosity, density, surface tension, and orifice diameter on bubble formation and presented some of their own more recent work. They also tried to clarify and reconcile the differences of opinion that existed among workers as to the effects of physical properties. Subsequently, Habennar and Morton $(7)$ investigated the rising velocity of various sizes of single bubbles in liquids with various viscosities and surface tensions. They reported that the velocity of rise of a bubble appeared to be dependent on the viscosity and surface tension of the solution if the bubble diameter was less than $0.6 \mathrm{~cm}$ and independent of these properties for larger bubble diameters. Other experimenters $(4,9,11)$ have investigated the formation of bubbles from orifices, using a continuous 
flow of air. They found that air-flow rate and orifice diameter affect the diameter of the bubble more than do the viscosity and density of the solution. These prior studies indicated that in the present.work the air-flow rate would probably have a significant affect on the mixing rate, but the affect of solution properties would be unimportant.

The effect of bubbles on the mixing is apparent when looking in the top of the tank. As the mixture of bubbles and solution rose in some areas of the tank, the solution descended in the areas of the tank that contained no bubbles. Verschoor $(14)$ discussed this in terms of the difference in densities of the mixture of air and solution and of the solution without bubbles. Fosset(6) discussed the mechanism in terms of the momentum of the fluid issuing from the orifice and how it imparts momentum to the bulk fluid and, thus, causes circulation. Bryn $(2)$ mentioned the least obvious influence--that each bubble forming in the bottom of the vessel represents a spherical surface, or film, of liguid that is initially of the sompnsition of the liquid at the bottom of the tank and that it then is displaced as the bubble rises. He stated that smaller vulules, resemhling inflexible spheres, entrain liquid in the vortex that follows them whereas larger bubbles wobble so much they continually slued their vortex and, presumably, shed their surrounding film more rapidly than do smaller bubbles.

\section{GENERAL EXPERIMENTAL CONSIDERATIONS}

\section{Apparatus}

A 30-inch diameter stainless steel tank about 48 inches high, with a jacket 22 Inches wide arousu the lowcr part of the side of the tank (14.2 square feet of heating surface), was selected for the test studies. The rcvoreed-disher-head bottom and the diameter of this tank made it similar to many of the process vessels in the ICPP. A 24 -inch alumeter stainloce stee.l disher head was welded on the tank to form a bottom jacket giving an additional heat transfer area of 3.34 square I'eet. The steam and condensale piping to the side and bottom jackets allowed the jackets to be used individually or together. By adding the bottom jacket the tank was made to simulate more closely the 36-inch diameter process evaporator in the ICPP which has a single jacket cuvering the sides and bot.tom. An over-all view of the tank and the auxiliary equipment is given in Figure 1. The condenser above the tank contained about 55 square feet of heat transfer area. Eight of the sixteen sample tubes that were installed in the tank entered through the unjacketed knuckle radius of the t.ank bottom, and eight of them were installed through the side of the tank above the side-heating jacket. These can be seen on rigure 1. These sixteen sample tubes, arranged in two eight-tube groups, terminated within the tank at three different distances from the tank wall (2 inches, 5 inches, and 7 inches) and at four different elevations from the bottom of the tank ( 8 inches, 16 inches, 24 inches, and 30 inches). With 36 inches of solution in the tank, even the longest sample tube was adequately purged in 3 seconds.

One group of sampling valves is shown in Figure 2. The quick-opening Hoke valves could be operated individually, or any combination of them in 


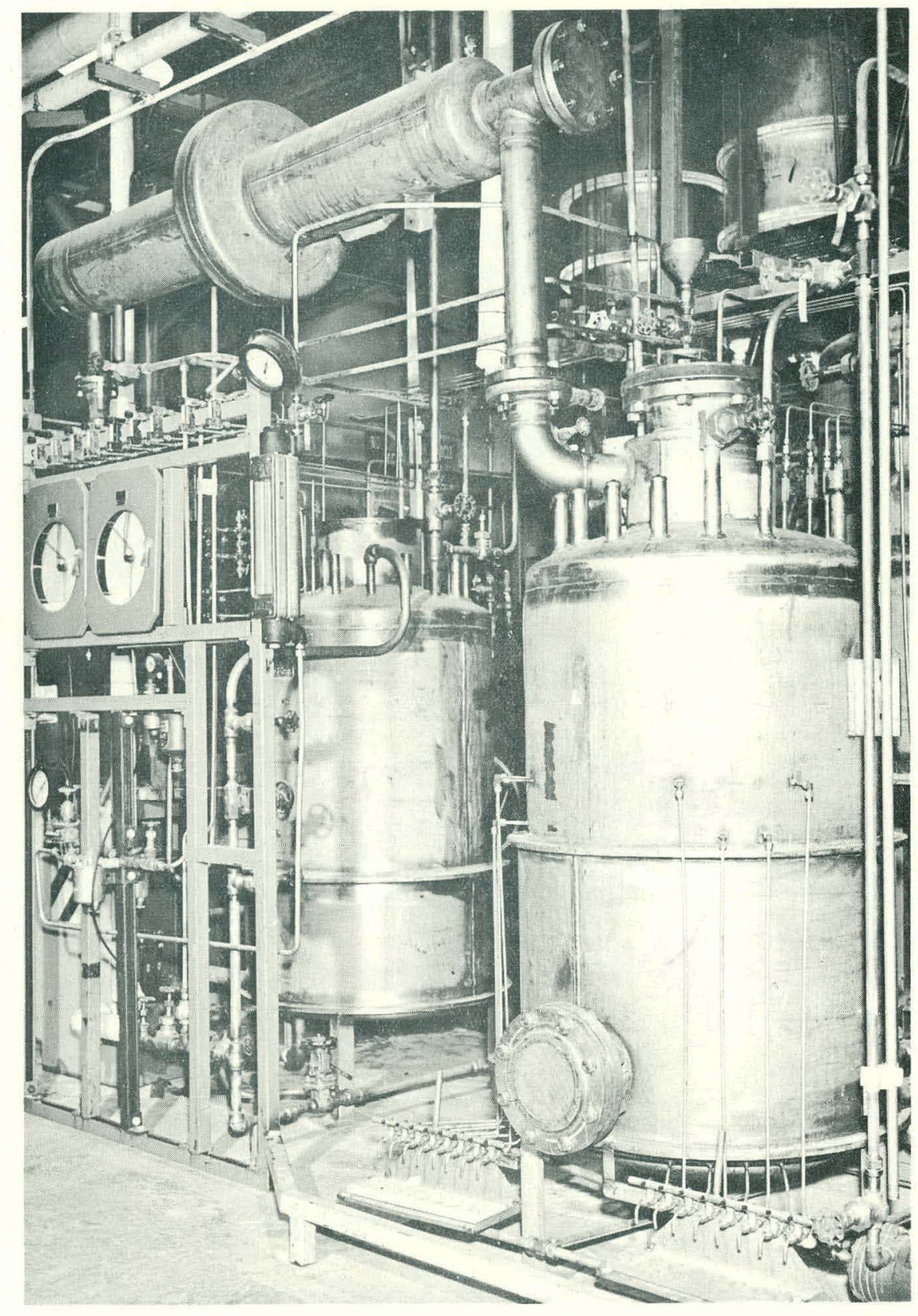

Figure 1. Photograph of the Test Vessel, Samplers, Condenser, and Instruments. 


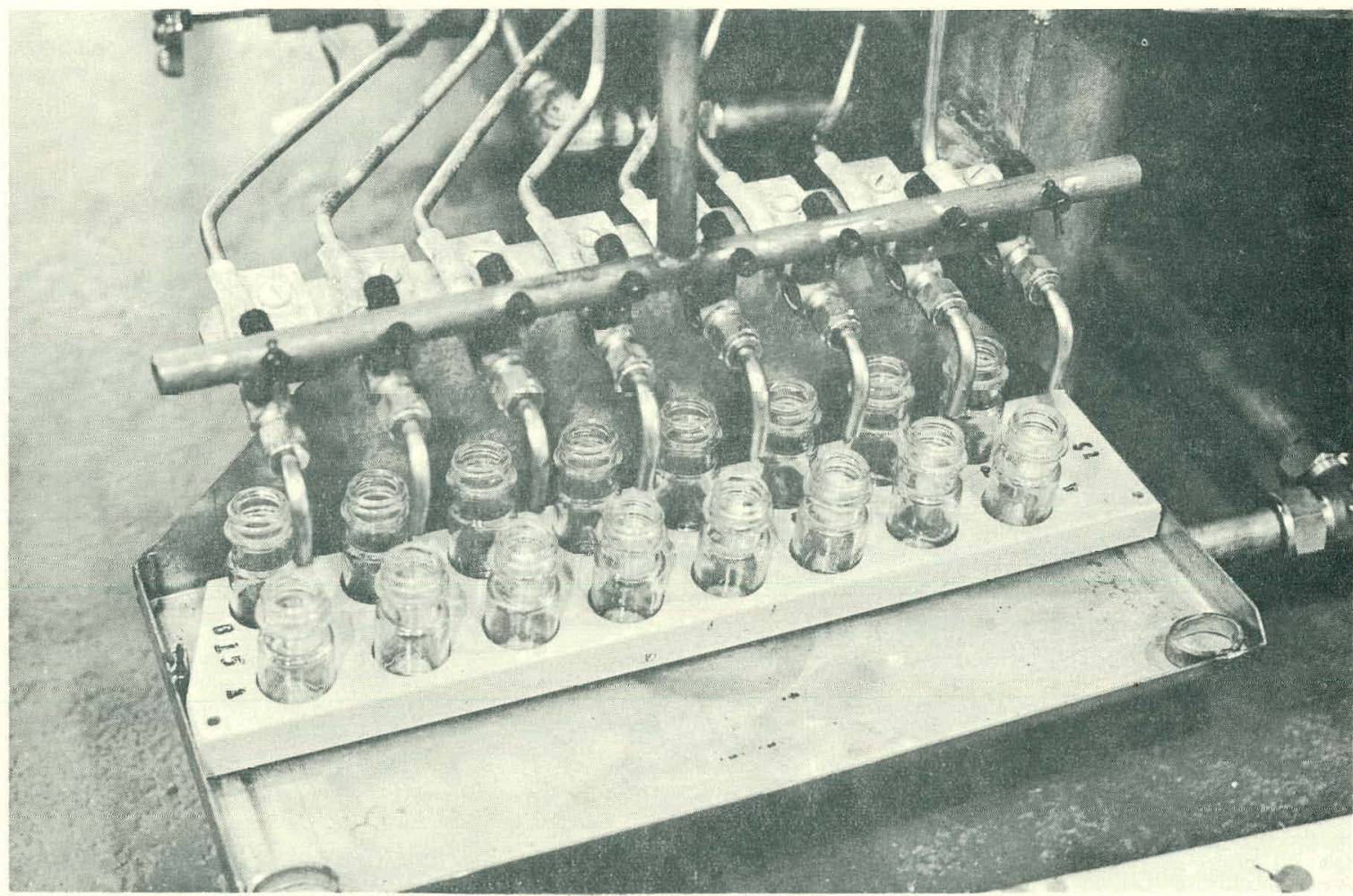

Figure 2. Photograph of Sampling Mechanism and Sample Bottle Holder.

either group could be operated simultaneously with the gangbars. Figure 2 also illustrates the numbered sample blocks that were used to hold and index the sample bottles. Each of the two rows of holes in the blocks held eight 9/16-ounce sample bottles. Samples could be taken every 10 seconds if necessary with a simple push-puld operation of the block to position the bottles under the tubes. A standard technique for operating the sample valves and the tracer addition valves helped prevent unnecessary Illuctuations in the results.

The sparge air, at about 22 psig, was released through seven equallyspaced 3/32-inch diameter orifices drilled in the 1/2-inch pipe forming the distributor ring. 'They were directed inward toward the center of the tank and downward at an angle of $15^{\circ}$ from the horizontal. The tracer was added through the air distributor via the pressure pot on the top of the tank. The sparge ring was supported about 1 I/2 inches from the bottom of the tank.

The flanges on the top and on the side of the tank permitted the packing, $1 / 2$-inch Raschig rings with 3/16-inch walls or $11 / 2$-inch Raschig rings with $1 / 4$-inch walls, to be inserted and removed. Aside from two circles of 1 l/2-inch Raschig rings that were hand-placed around the bottom to avoid blocking an orifice, the Raschig rings were dumped into the tank to give a random pack. Twenty-four inches of water were used in the tank during packing to buffer the impact of the falling rings and reduce breakage. 
Tracer Selection and Method of Analysis

A concentrated cupric nitrate solution was selected as the tracer because it was readily available, economical, and non-toxic. Besides meeting the requirement of being stable in the test solutions, it was detectable in the relatively low concentration range of one gram of cupric nitrate per liter with a colorimetric analytical method, using a cell with a 5-centimeter absorption path in a Beckman Model B spectrophotometer. The method was based on the peak absorbency of the copper complex with ethylene diamine tetraacetic acid (EDTA) occurring at a wave length of 735 millimicrons. The color was developed by adding a 1 to 4-milliliter aliquot of the test solution to 20 milliliters of a color-developing reagent, $0.5 \mathrm{M}$ EDTA - $0.5 \mathrm{M}$ diammonium citrate adjusted to a $\mathrm{pH}$ of 5.7 . This method had an analytical coefficient of variation of 0.8 per cent.

It was necessary to add about $300 \mathrm{ml}$ of 60 per cent nitric acid to the water in each water-test to prevent the precipitation of copper hydroxide. The sedimentation of copper hydroxide in some sample bottles caused a few analyses to be unreliable.

\section{Data Interpretation Methods}

The time required for "complete" mixing in each test was determined, as illustrated in Figure 3, by the point of intersection of the curve through the data points and the horizontal zone superimposed on the final concentration. The data points were the averages of the copper concentrations at each sampling time during the tests. 'l'he width of the horizontal zone was defined as twice the standard deviation of the method of analysis.

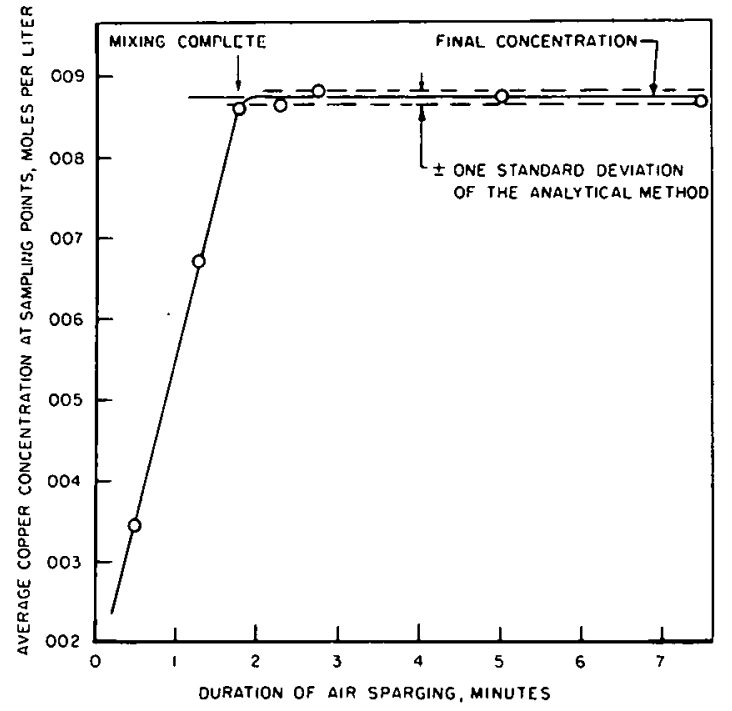

CPP-S-1780

Figure 3. Determination of Time for Complete Mixing for a Typical Rurn, (30" Diameter Tunk, No Packing, Water, $0.37 \mathrm{scfm}$ of Air per Square Foot of Tank Crose Section).
It was possible to check the "complete" mixing time for any no-packing test by comparing the standard deviation of the samples taken in each interval with the standard deviation of the analytical method. Usually the standard deviation of the samples taken in the first sampling interval was very large relative to the standard deviation of the method of analysis. The value of the standard deviation became smaller for each succeeding interval. The "complete" mixing time was defined (for this secondary method of determination) as the time corresponding to the intersection of the curve drawn through the points representing the standard deviation of the samples, with the horizontal line defined by the standard deviation of the method of analysis. The standard deviation was readily obtained with the simplified approximation suggested by Duncan $(5)$. This secondary method was only applicable to the tests made using 
the tank without packing. With packing, the standard deviation equalled the standard deviation of the analytical method before the average concentration at the sample tubes reached the final concentration, because of the holdup, in the bottom of the tank, of tracer-rich solution.

\section{Evaporation Test Procedures}

The increments of condensate from each test were collected and weighed semi-automatically in a fifty-gallon tank on a platform scale. The usual error caused by equipment bias in measuring the continuously increasing mass was minimized by using an electric timer actuated by a pair of counter-balanced switches connected to the beam. When the scale balanced with a pre-set weight of condensate, the switch stopped the timer at essentially the same position of beam-swing in each test.

The nver-all heat tranefer driving forcc botween the steam in the jacket and the boiling solution was determined f'rom the indicated sletu pressure and the temperature recorded by the thermocouple in the tank. There were two possible errurs that could affect the indirated temperature of the thermocouple. First, the thermowell could be cooled slightly by convection when sparge air entered rrom an adjacent orifice. Second, the thermowell could lose heat by conduction through a tack-weld to the sparge ring. The effect of these errors complicated the medsurement of thc boiling point, which was continually changing while aluminum nitrate sulutions were evaporating. A calibration, based on a series of water evaporations with various jacket conditions and sparge conditions, made it possible to correct the boiling point temperature.

\section{DISCUSSION OF MIXING EXXEHRIMEITSS}

\section{Effects of Packing on the Mixing Time}

The presence of the Ragchig-ring nasking in the tank, or, more exactly, the presence of the many small interstices within the mass of packing, probably permitted some of the tracer to be undisturbed hy the rising air bubbles and, as such, hindered the air sparge mixing. Three eets of tests, the first using no packing; the second using 1 1/2-inch Raschig rings and the third using $1 / 2$-inch Raschig rings were made to evaluate the effect of packing on the mixing rate. Each set of tests also covered the range of air-flow rates from 0.37 to 3.15 scfm per square foot of tank cross section. It was not unexpected that the use of the 1/2inch Raschig rings, having the greatest number of the smallest interstices, resulted in the longest. mixing times.

Figure 4, which was plotted on semi-logarithmic graph paper in order to show conveniently the magnitude of the difference in the mixing times, summarizes all the data for the variety of packing, solutions, and airflow rates that were used. It rcvcalo that the presense of the $11 / 2$-inch Raschig rings, as compared with no packing, caused a fourfold to tenfold increase in the minimum time required to mix tracer into water, depending on the air-flow rate used. For example, at the air-flow rate of $3.15 \mathrm{scfm}$ per square foot of tank cross section, water in the unpacked tank was mixed 


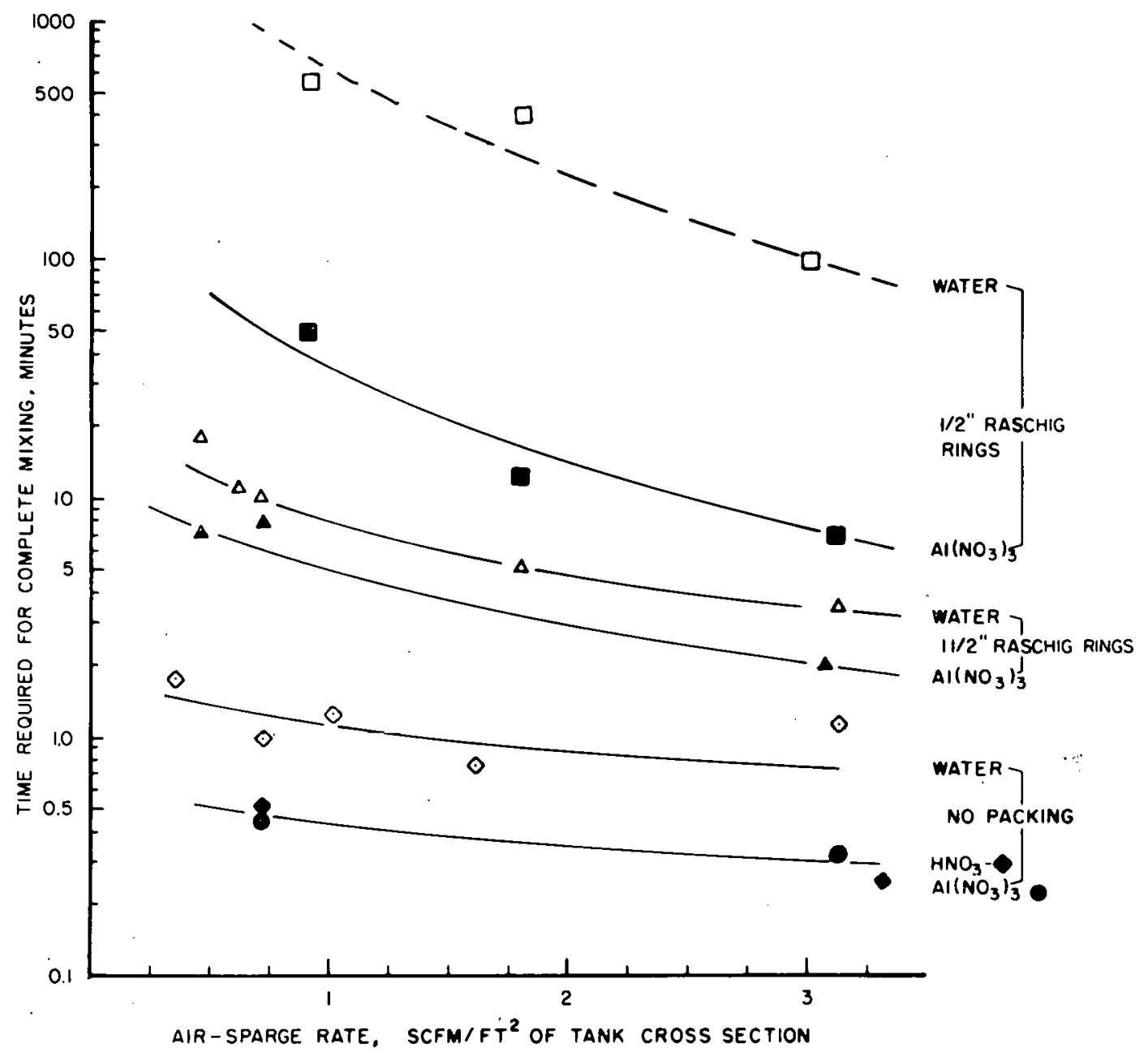

CPP $-5-1789$

Figure 4. 'bifect of Packing and Sparge Air on the Time Required to Mix Cupric Nitrate into 2.2M Aluminum Nitrate and into Water. (Method of Cupric Nitrate Additions Illustrated in Figure 6).

in less than a minute, but with the 1 1/2-inch Raschig-ring packing, mixing required four minutes. A comparison of the data obtained with the 1/2-inch Raschig-ring packing and with no packing in the tank showed that at the maximum air-flow rate $(3.15 \mathrm{scfm} / \mathrm{ft} 2)$ the presence of this packing caused a 125-fold increase in the time required to produce complete mixing, and at a lower air-flow rate ( 1 scfm/ft2) it caused a 500fold inilease lis lite lime required to produce mixing.

Figure 4 shows that the data from each set of tests could be represented by a zone between the higher-density solution (aluminum nitrate) line and the lower-density solution (water) line. The separation bstween each of the three principal sets of data indicates that the size of the packing has a pronounced effect on the mixing rate. 

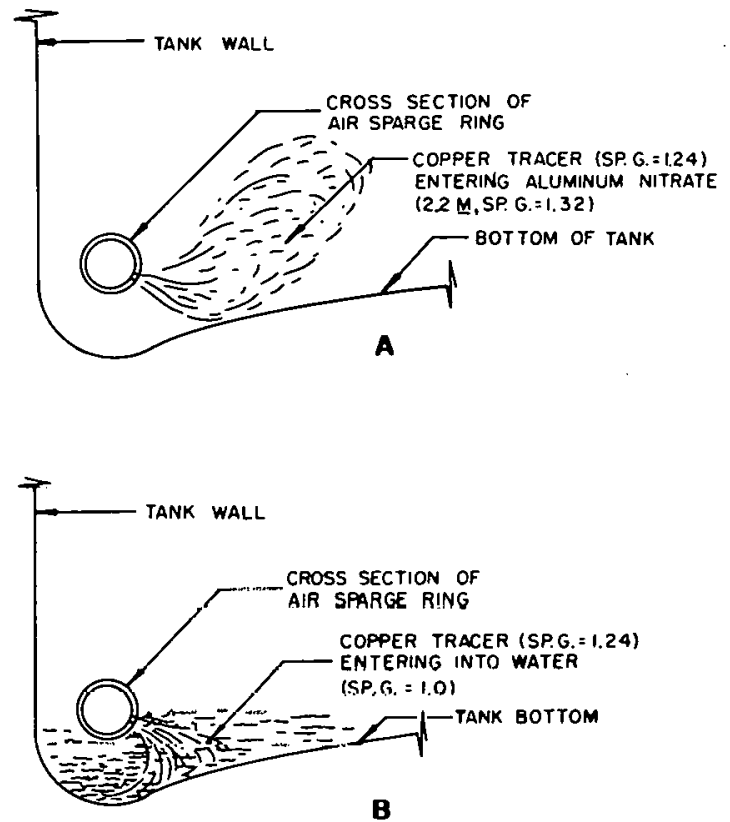

Figure 5. Illustrations of Cupric Nitrate Addition into the Bottom of the Vessel.

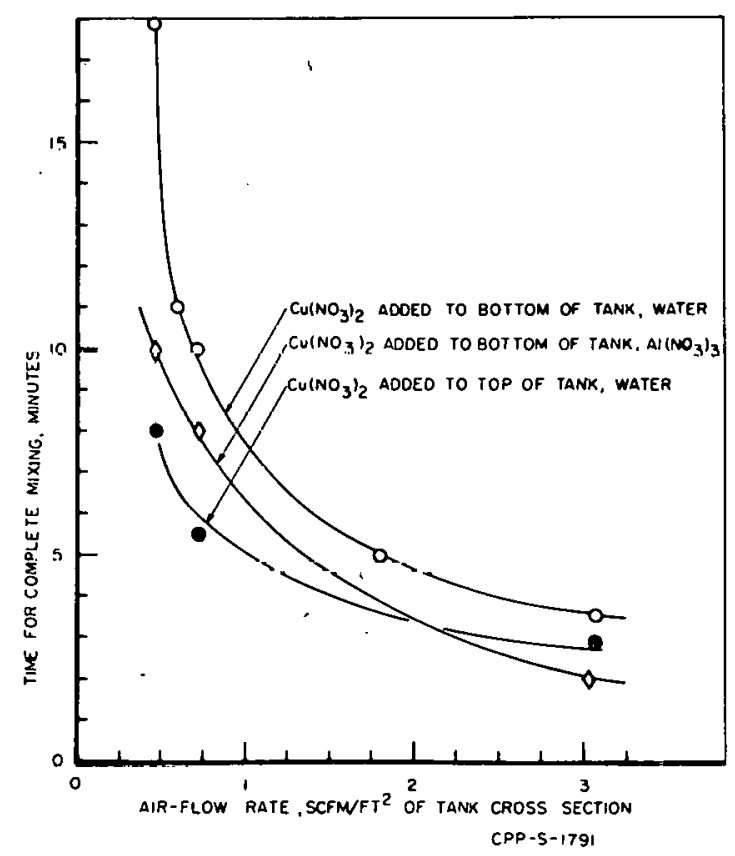

Figure 6. Effect of Adding Tracer into the top of the Vessel. (30" Diameter Tank, I I/2-inch Raschig Rings).
The separation between the aluminum nitrate-data curve and the water-data curve for each type of packing indicates, for different solution densities, how the design of the air distributor and the vessel bottom influences the mixing rate. The behavior of cupric nitrate $(\rho=1.24$ $\left.\mathrm{g} / \mathrm{cm}^{3}\right)$ in water $\left(\rho=1.0 \mathrm{~g} / \mathrm{cm}^{3}\right)$ was observed in the tank without packing in one instance by adding the tracer slowly and by watching it form a blue pool under the air distributor. Figure 5 illustrates how the tracer can rise or fall as it emerges into aluminum nitrate $\left(\rho=1.32 \mathrm{~g} / \mathrm{cm}^{3}\right)$ or into water $\left(\rho=1.0 \mathrm{~g} / \mathrm{cm}^{3}\right)$, respectively. Although it is probable that only a small portion of the tracer diffuses under the air distributor when it is ejected rapidly into an unpacked tank and followed immediately with sparge air, the presence of the packing probably accentuates the tendency of the tracer to settle under the distributor. Considering ( 1 ) that only one to two liters of tracer is used in each test, (2) that some tracer can diffuse under the air distributor, and (3) that the definition of good mixing as based on the standard deviation of the analytical method, these are rabher rigid standardo for evaluating the ability of spargers to mix solutions thoroughly in either packed or unpacked tanks.

In one serles of three tests the tracer solution was introduced into the top of the tank containing water and $11 / 2-i n c h$ Raschig rings. Figure 6 is a plot of these data and of the data from the previous comparable tests where the tracer was added to water and 2.2M aluminum nitrate via the sparge ring at the bottom; it shows that the time intervals required for mixing the tracer into the tark of water, when the tracer is added to the top of the tank, are slightly less than the respective time intervals required for mixing it into the aluminum 
nitrate when it was added into the bottom of the tank. This is evidence that longer mixing times for the less-dense solutions were caused largely by the confinement of some tracer in the bottom.

In another test, the tracer was added to the top of an unpacked tank containing 60 per cent nitric acid. The result from this test was compared with the result obtained by adding tracer to the bottom of the tank containing 60 per cent nitric acid. There was no significant difference in the mixing rate between the two addition methods for a solution with this density. Evidently no tracer settled into the dead-space under. the air distributor when the tank contained no packing. Differences among the mixing times of these solutions are difficult to measure because the mixing is very rapid relative to the maximum sampling frequency.

Pattle(12) and Verschoor(14) described another possible mechanism that may cause concentrated aluminum nitrate solutions to be mixed more rapidly than is water. They found that concentrated solutions of strong electrolytes, such as 2.2M aluminum nitrate, inhibited the coalescence of air bubbles that were $\bar{r}$ ising within them; thus, more small bubbles are present in aluminum nitrate than are present in water at similar airf'low rates. The mixing induced by the rising envelopes of liquid around each bubble should be greater for small bubbles than for larger bubbles involving the same flow of air even though the small bubbles rise more slowly. This is because the total ared of the air-liquid interface increases as the diameter of the bubbles decreases.

An investigation by Liebson and co-workers $(9)$, in which they photographed bubbles being created at an orifice in the bottom of the tank, showed how air-flow rates, involving Reynolds numbers of 700 to 30,000 at the orifices, affected the slze and population of bubbles. They found that single bubbles of uniform size were formed when the Reynolds number in the orifice went below 2,000. At higher air-flow rates doublets and triplets were formed, and at the highest air-flow rates a multiplicity of smaller bubbles formed. Their pictures show that many of the larger, more highly distorted bubbles are literally torn apart by the momentum of the gas and liquid moving away from the orifices. Similar results were also observed in the experiments associated with this study.

\section{Viscosity Effects}

The possible effect of viscosity on the rate of mixing was studied by making a series of tests with 60 per cent nitric acid. These tests used air-fllow rates comparable to those used in the previously described tests in which 2.2M aluminum nitrate was used. Since 2.2M aluminum nitrate and 60 per cent nitric acid have very nearly the same density $(\rho=1.32$ $\mathrm{g} / \mathrm{cm}^{3}$ ) but different viscosities, comparison of results from similar tests using these two solutions should indicate the existence or non-existence of viscosity effects. The room temperature viscosity of 60 per cent nitric acid is about 1.1 centipoises and of $2.2 \mathrm{M}$ aluminum nitrate about 8.0 centipoises. The agreement between the two types of data points on the bottom line of Figure 4 illustrates that the viscosity of solutions in the unpacked tank has no significant effect on the mixing times. 
Effect of Air-Flow Rate and Packing on the Liquid Turbulence

As an adjunct to the mixing studies, the solution being mixed was photographed to compare the turbulence at the surface of the solution at various air-flow rates. These photographs can only show turbulence in terms of the size and number of intact bubbles on the surface and cannot illustrate the velocity of the bubbles moving from the area near the walls toward the area near the center of the vessel. The bubbles on the surface of the liquid in the tank when it was packed with the $1 / 2-i n c h$ Raschig rings appeared to have approximately the same lateral velocity on the surface as did the bubbles on the surface of the liquid surrounding the $11 / 2$-inch Raschig-ring packing. This indicates that the liquid surrounding the $1 / 2$-inch Raschig-ring packing in a tank would be mixed more rapidly than shown on Figure 4 were it not for the severe test conditions of using a small volume of tracer and the resulting confinement of some solution by the 1/2-inch Raschig-ring packing In the bottom of the tank.

Wyures 7 rul 3 , which arc photographo with the $11 / 2-i n c h$ rings in the tank, iliustrate, respectively, the agitation caused by 3.15 and $0.73 \mathrm{scfm}$ of air per square foot of tank cross section. Figures 9 and 10 depict the agitation produced at the same air-flow rates, but with the $1 / 2$-inch rings in the tank. Figures 11 and 12, taken with rio packing in the tank, are presented to complete the comparison of the effect of packing on the turbulence in the tank. Except for the presence of additional foam at the surface of the solution observed in Figures 7 and 8 , which illustrates the retarded bubble coalescence in an aluminum nitrate solution, the solution turbulences in each of the six photographs were very similar.

The photographs of the liquid in the tank without packing provide a basis for comparing these data with Kauffman's (8). Comparison is difficult, however, because he described the extent of agitation in such general terms as "violent", using 3.1 scfm of air per square foot of tank cross section, and "moderate", using 0.65 scfm of air. Nor was his study made on the basis of time required for complete mixing. Addeddifficulties rise from the fact that he used nine feet of liquid in the tank and did not describe the air distributor or give the diameter of the tank.

It could be'stated, for the present tests, that the solution moved around "violently" when 3.15 scfm of air per square foot of tank cross section were used, giving complete mixing in $3 / 4$ minute, and "moderately" when the $0.73 \mathrm{gcfm}$ of air per square font of tank crnss section was used, giving complete mixing in $11 / 4$ minutes. Although these photographs show a visible difference in the degree of agitation, the times required for complete mixing were so short relative to the minimum sampling interval, that little significance can be placed on the difference.

Expansion Due to Air Holdup

The presence of the packing caused the air bubbles to rise more slowly and, in turn, the bubbles caused the solution surrounding the packing to expand. This expansion was visibly evident in the actual 


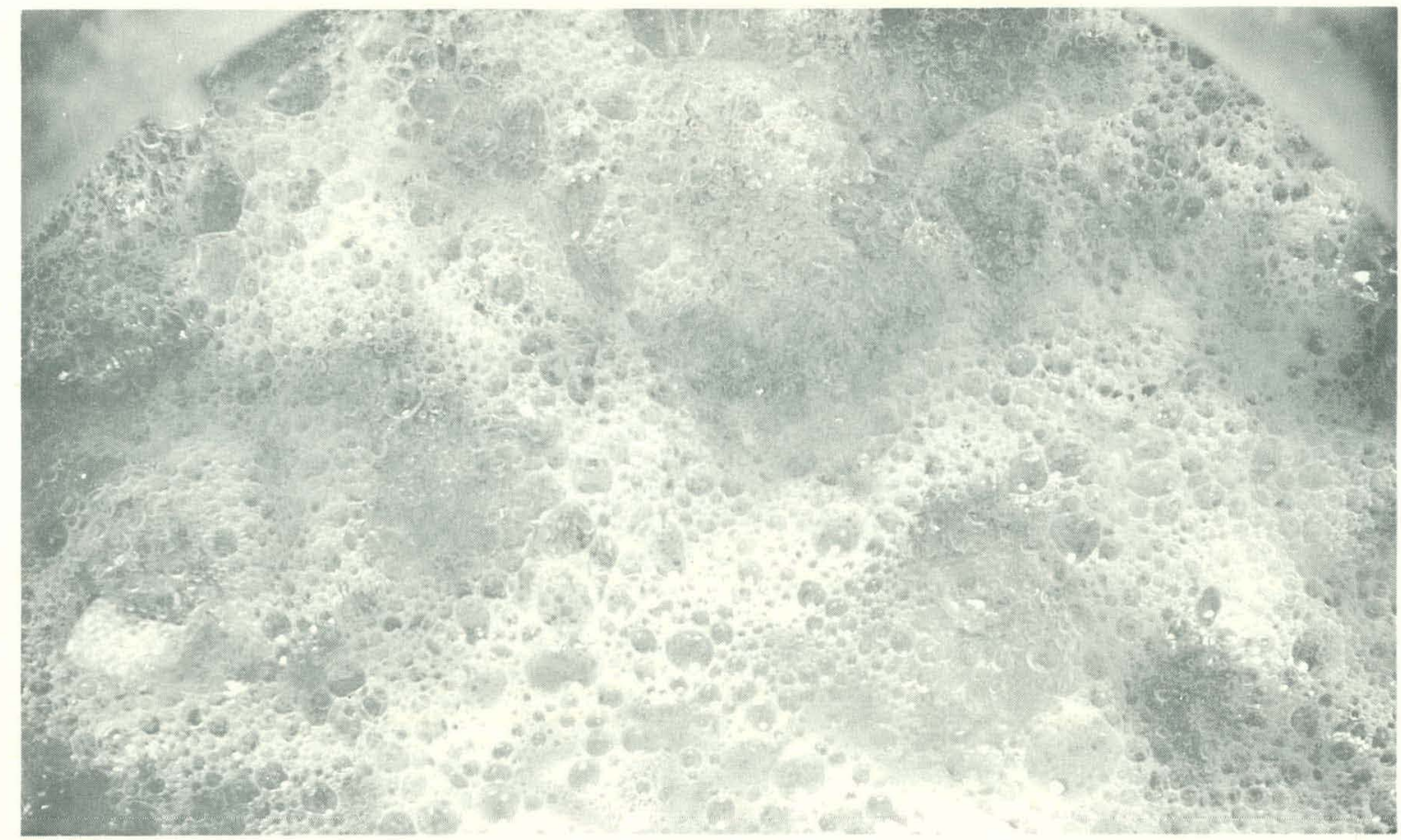

Figure 7. Turbulence in a Vessel Packed with 1 1/2-inch Raschig Rings Using $3.15 \mathrm{scfm}$ of Sparge Air per Square Foot. (1.1M Al $\left(\mathrm{NO}_{3}\right)_{3}$; 30" Diameter Tank; 36" of Packing).

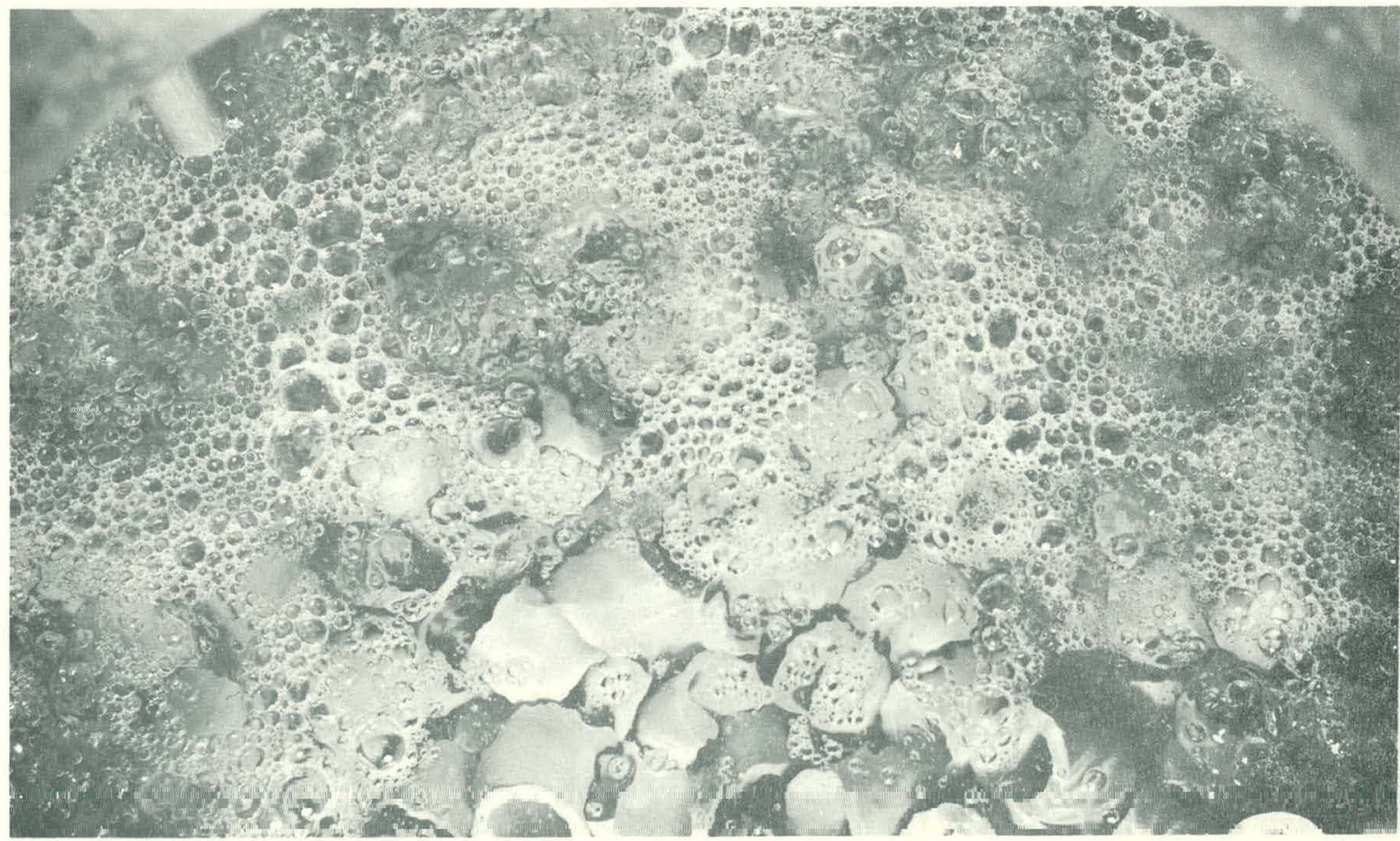

Figure 8. Turbulence in a Vessel Packed with 1 1/2-inch Raschig Rings Using $0.73 \mathrm{scfm}$ of Sparge Air per Square Foot. (1.1M Al $\left(\mathrm{NO}_{3}\right)_{3}$; 30" Diameter Tank; 36" of Packing). 


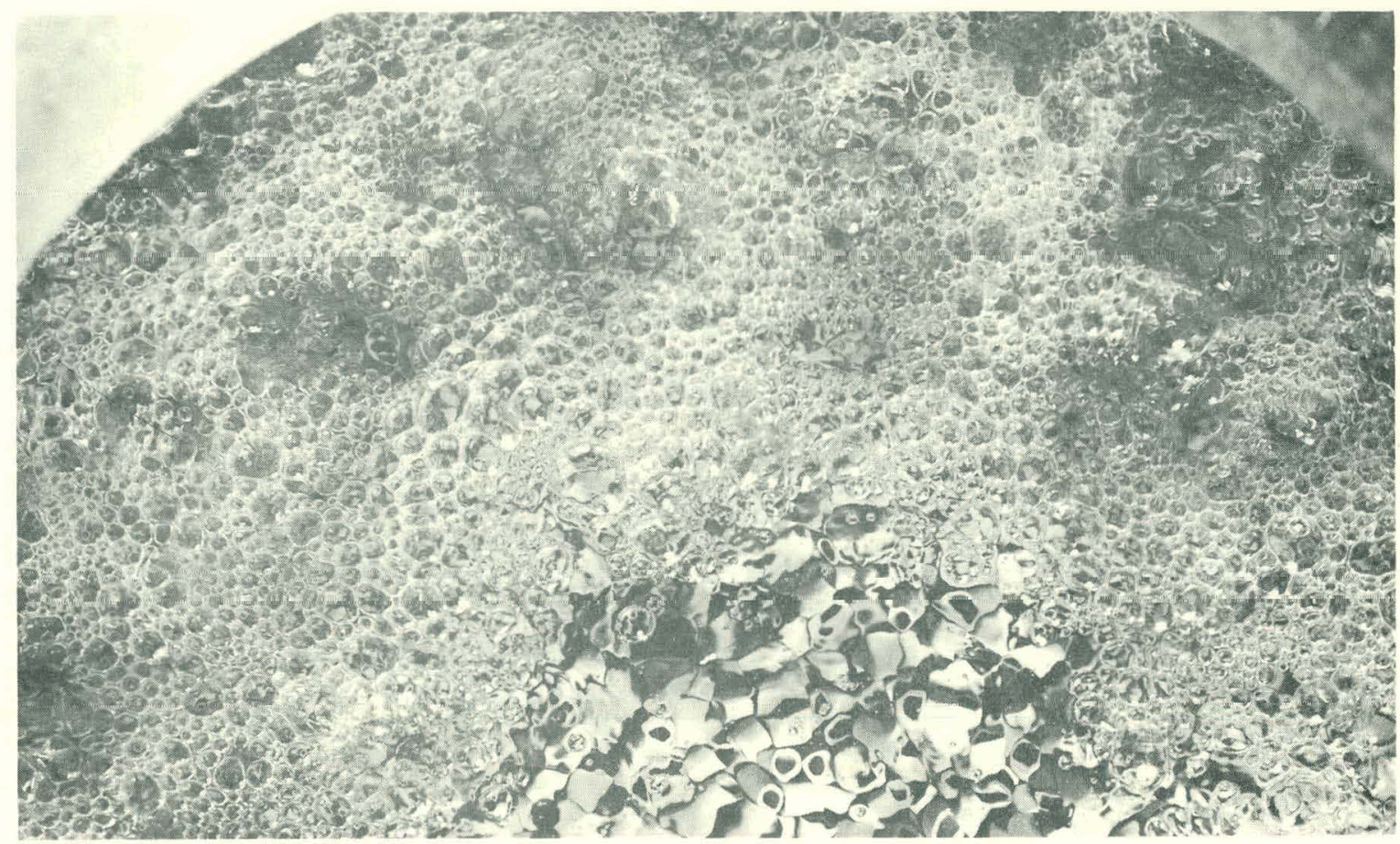

Figure 9. Turbulence in a Vessel Packed with 1/2-inch Raschig Rings Using $3.15 \mathrm{scfm}$ of Sparge Air per Square Foot. (Water; 30" Diameter Tank; $36^{\text {" }}$ of Packing).

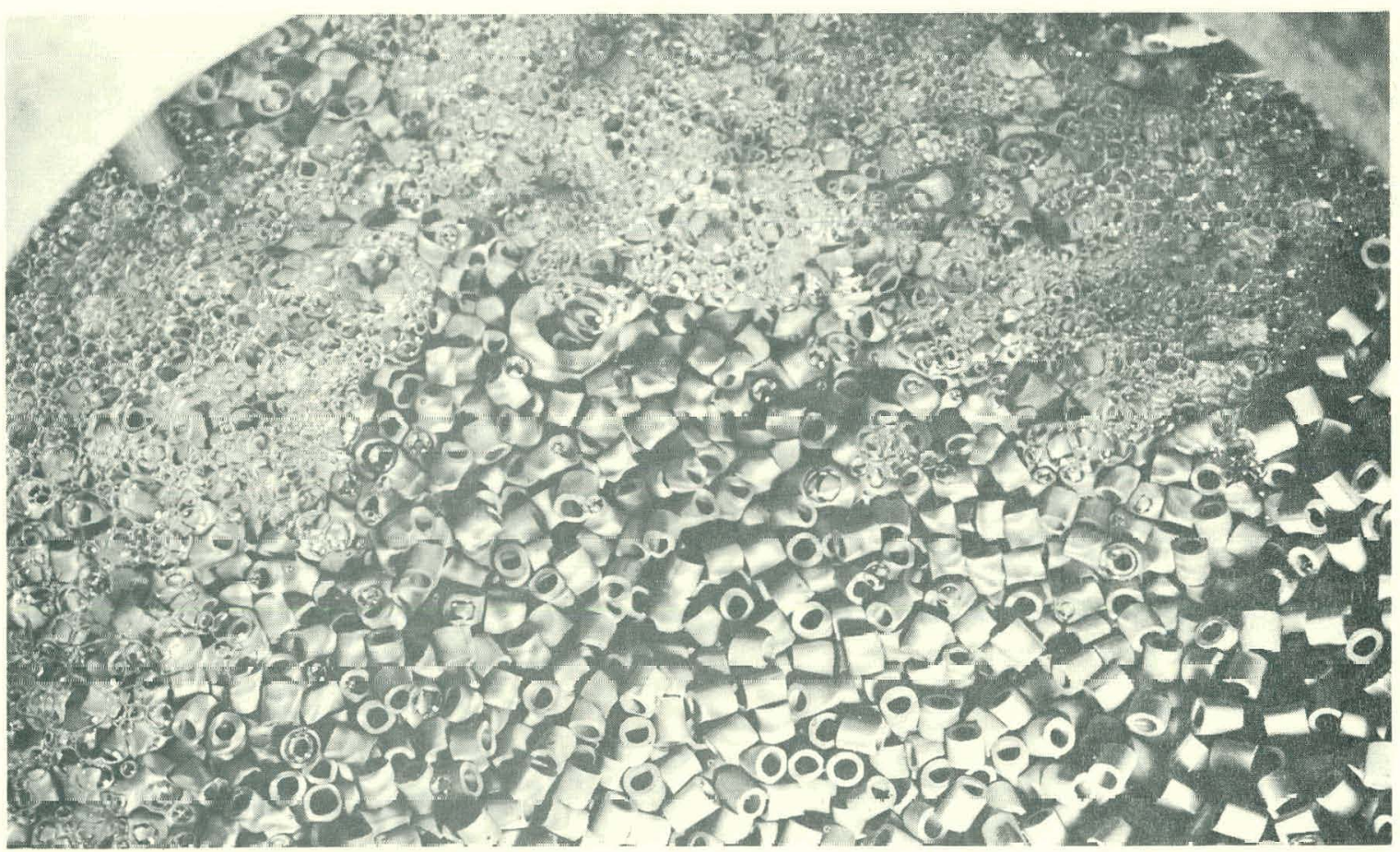

Figure 10. Turbulence in a Vessel Packed with 1/2-inch Raschig Rings Using 0.73 scfm of Sparge Air per Square Foot. (Water; 30" Diameter Tank; 36" of Packing). 


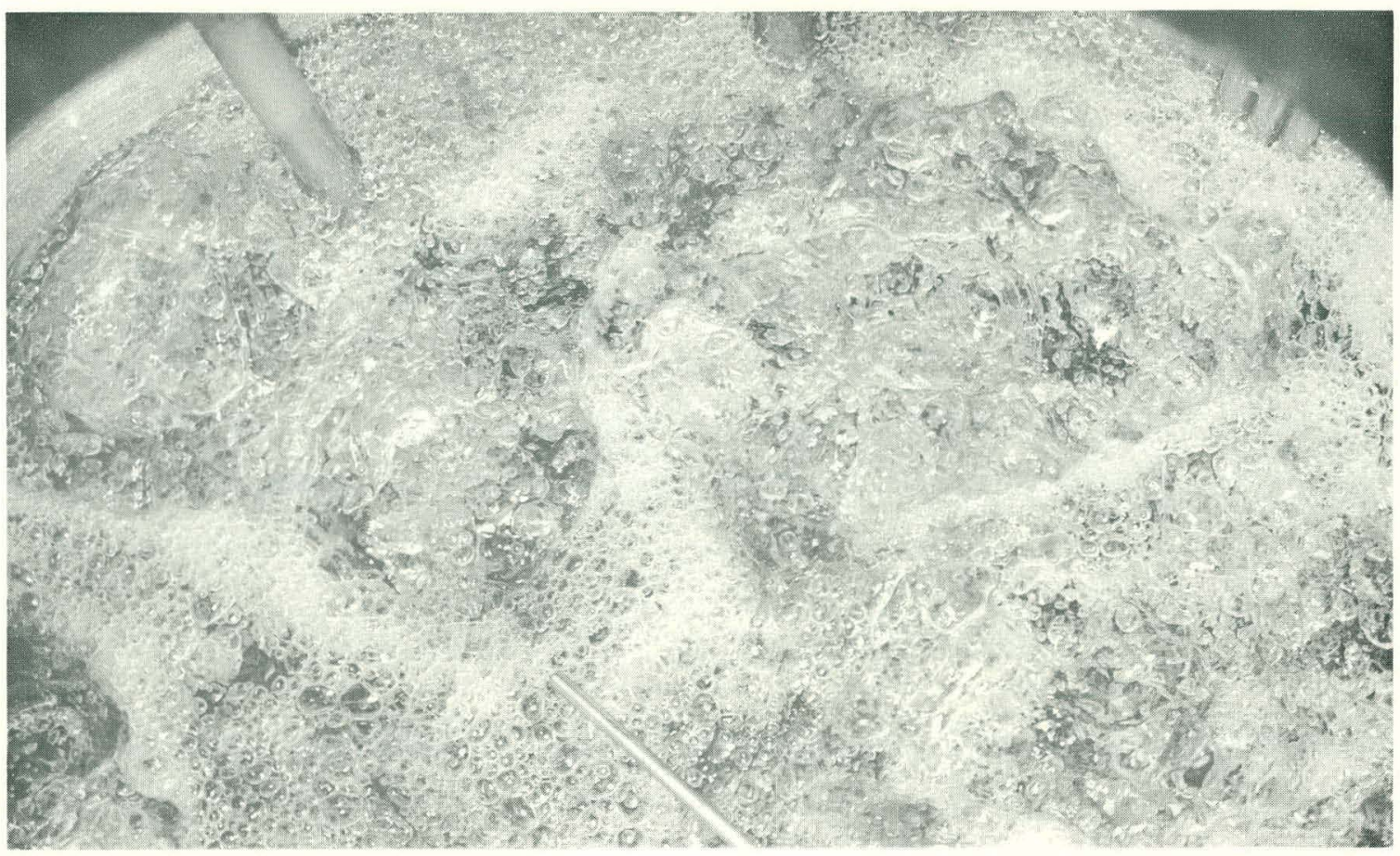

Figure 11. Turbulence in a Vessel Without Packing Using 3.15 scfm of Sparge Air per Square Foot. (Water; 30" Diameter Tank).

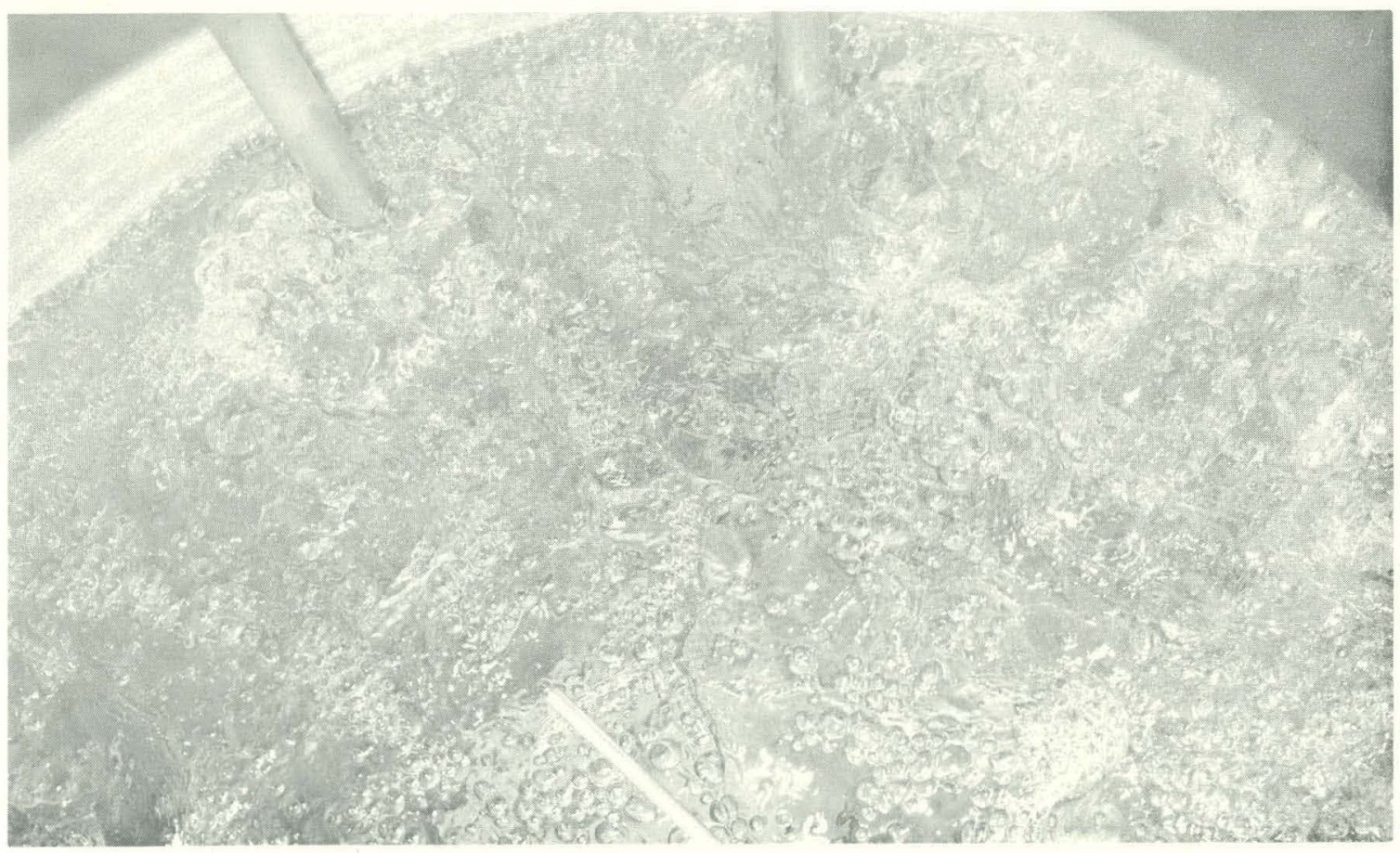

Figure 12. Turbulence in a Vessel Without Packing Using 0.73 scfm of Sparge Air per Square Fool. (Waler; 30" Diameter Tank). 


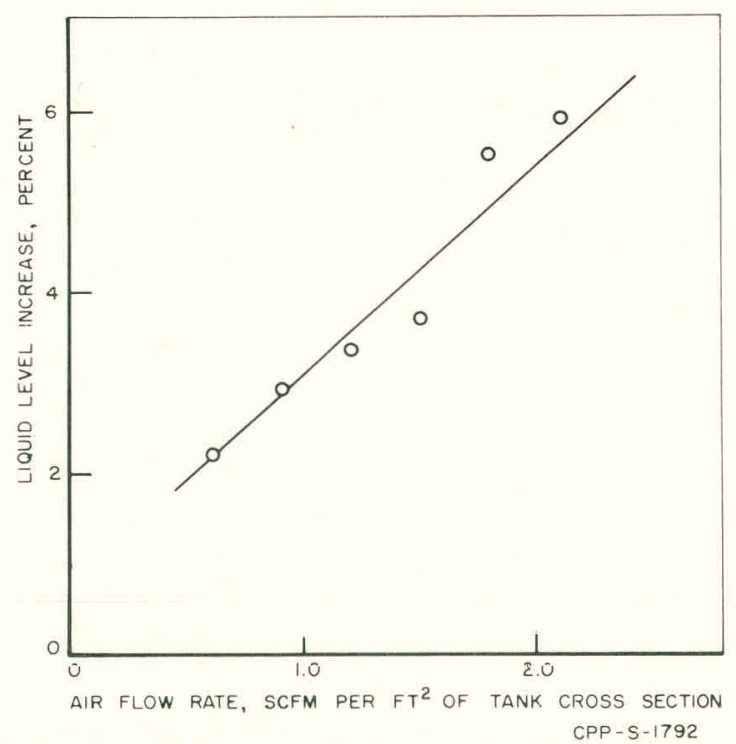

Figure 13. Effect of Air-Flow Rate on Expansion of Liquid in a Tank racked with $1 / 2$-inch Raschig Rings. (30" Diameter Tank; Water).

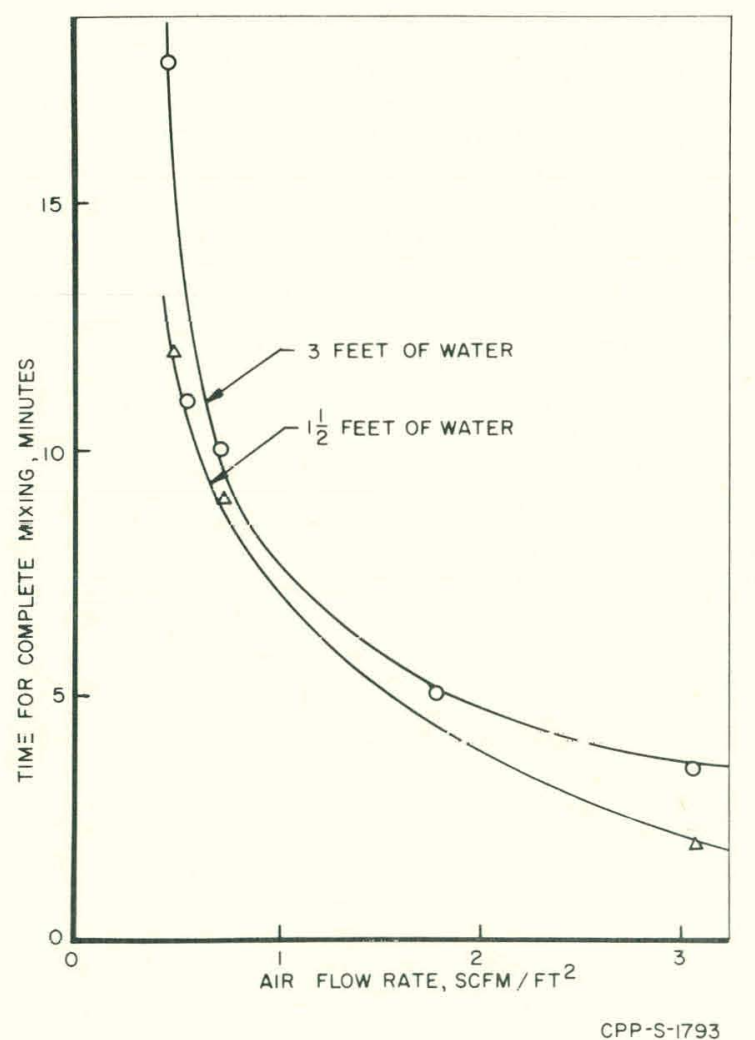

Figure 14. Effect of Liquid Level on the 'l'ime Required f'or Complete Mixing. (Water; 30" Diameter Tank; 1 1/2" Raschig Rings). tests, however, it is not readily evident in the photographs. A series of measurements was made to determine the increase in the water level resulting from the use of various air-flow rates when the 1/2-inch Raschig rings were used. These data, plotted in Figure 13, illustrate the expansion of the liquid as a function of the superficial gas velocity (scfm/ft2). Comparable measurements were not made with the 1 1/2-inch Raschig-ring packing in the tank or with no packing in the tank. However, a visual comparison of the unpacked tank with the packed tank showed that the tank without packing had the smallest increase in solution volume at any given airflow rate and the tank packed with 1 l/2-inch rings represented an intermediate case.

Effect of Liquid Level

Two series of tests were made to explore the effect of liquid level on the time required for complete mixing. In one series of tests, with no packing In the tank, there was no detectable difference in the mixing times for $11 / 2$ feet of water and for 3 feet of water at a given air-flow rate. In another series of tests, with the 1 1/2-inch Raschig rings in the tank, the data werc inconclusive because there were only three and four values at each liquid level. However, a plot of these dat,a, Figure 14, indiraties that with identical air-flow rates the smaller quantity was mixed more rapidly than the larger quantity, Although this opposes Kauffman's (8) conclusion that a given air-flow rate gives less apitation in 3 feet of liquid than in 9 feet of liquid, the difference'apparently arises because Kauffman evidently used a large storage tank, and with a 3-foot liquid depth only the liquid surface in the vicinity of the air inlet was agitated. Perhaps other portions in the liquid were unmoved until the liquid level was raised to about 9 feet. 
The unintentional combination of a relatively high-density solution with a low-density solution has been of interest because it was believed that if the high-density solution were uranyl nitrate and if it formed a layer in the bottom of the tank, it could be a criticality hazard. In order to obtain data on how well solutions of differing densities mix in a tank without packing, as well as with packing, a series of tests was made using 2.OM aluminum nitrate as the more-dense solution and pouring it into the water at the rate of 3 to $4 \mathrm{gpm}$. The counterpart tests, adding water to the $2 \mathrm{M}$ aluminum nitrate in the unpacked tank and in the packed tank, were also made to provide a ready comparison of the mixing induced by this technique.

Although in actuality only small volumes of concentrated uranyl nitrate solution would be added to a large volume of water or other dilute solutions, it was necessary to use about 40 gallons of each solution (roughly 16 inches in the tank) in order to have a measurable concentration of tracer in the samples. The mixing was thus affected by the duration of the addition and by the momentum of the falling stream. The distance from the nozzle to the surface of the solution varied from 32 to 16 inches.

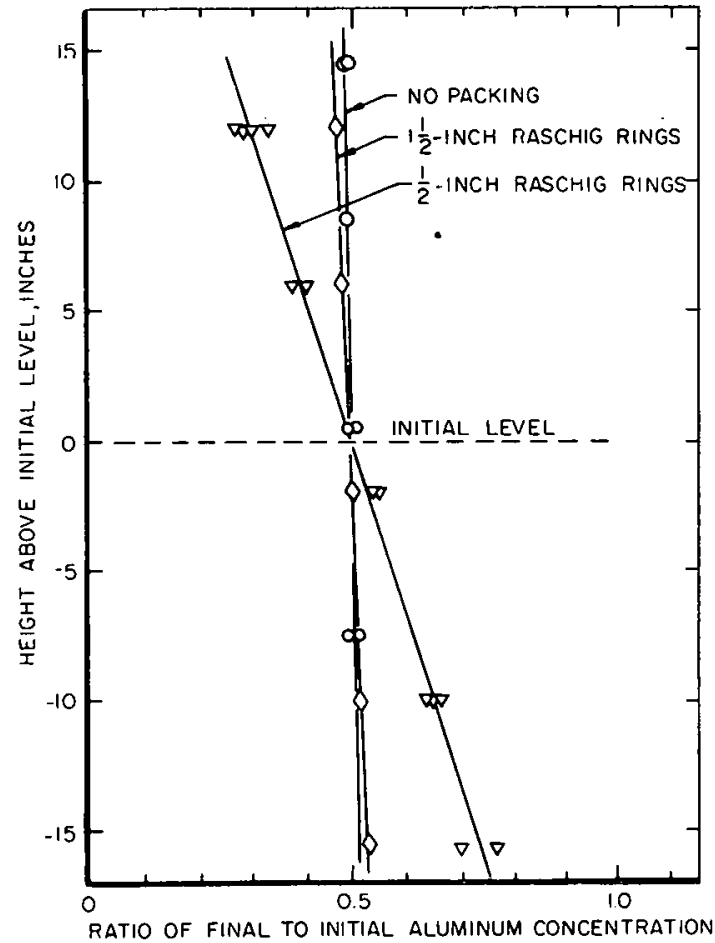

CPP-S-1794

Figure 15. Mixing Induced by Adding Concentrated Aluminum Nitrate on Top of Water. (30 Diameter Tank; No Sparge Air; Sampled Immediately after the Initial. Volume was Doubled).
Slight differences existed in the initial liquid level and in the initial concentrations, $\mathrm{C}_{O}$, of the aluminum nitrate used in each test. Nevertheless, these tests were compared on a common basis by converting the aluminum nitrate concentrations that existed before and after an addition to a ratio (final aluminum concentration/ initial aluminum concentration $-\mathrm{C} / \mathrm{C}_{\mathrm{O}}$ ) and by plotting it relative to the inftial elevation of liquid in the tank.

\section{Addition of Aluminum Nitrate Solution} to Wațer

These tests were made by adding $2 \mathrm{M}$ aluminum nitrate, uniformly spiked with cupric nitrate, into water in the test tank. Samples were taken as soon as the addition was complete. The values of the concentration ratio of the samples taken from the various elevations in the unpacked tank after the addition was complete are plotted in Figure 15. These data show that the more-dense solution, the concentrated aluminum nitrate, as indicated by the copper concentration, dispersed very uniformly throughout the unpacked tank. The slope of the line through. the data indicates that there is only 
a small concentration gradient with elevation. The data also show that the concentration was relatively uniform for the several radial positions at a given elevation in the tank. The maximum variation from the average concentration of any of the samples in this test with no packing in the tank was 1.5 per cent.

Comparable test's were made when the tank contained the 1/2-inch Raschig rings and 1 1/2-inch Raschig rings, and these data are also plotted on Figure 15. The 1 1/2-inch Raschig-ring packing slightly restricted the mixing of the aluminum nitrate as it descended through the water and the packing. The maximum concentration variation among the sample points in the tank in this case was 2.5 per cent. As the aluminum nitrate mixture settled through the water and 1/2-inch Raschigring packing, it achieved a much greater concentration gradient and gave a maximum concentration variation of 25 per cent, with the solution at the bottom of the tank being more concentrated in aluminum nitrate than that at the top of the tank.

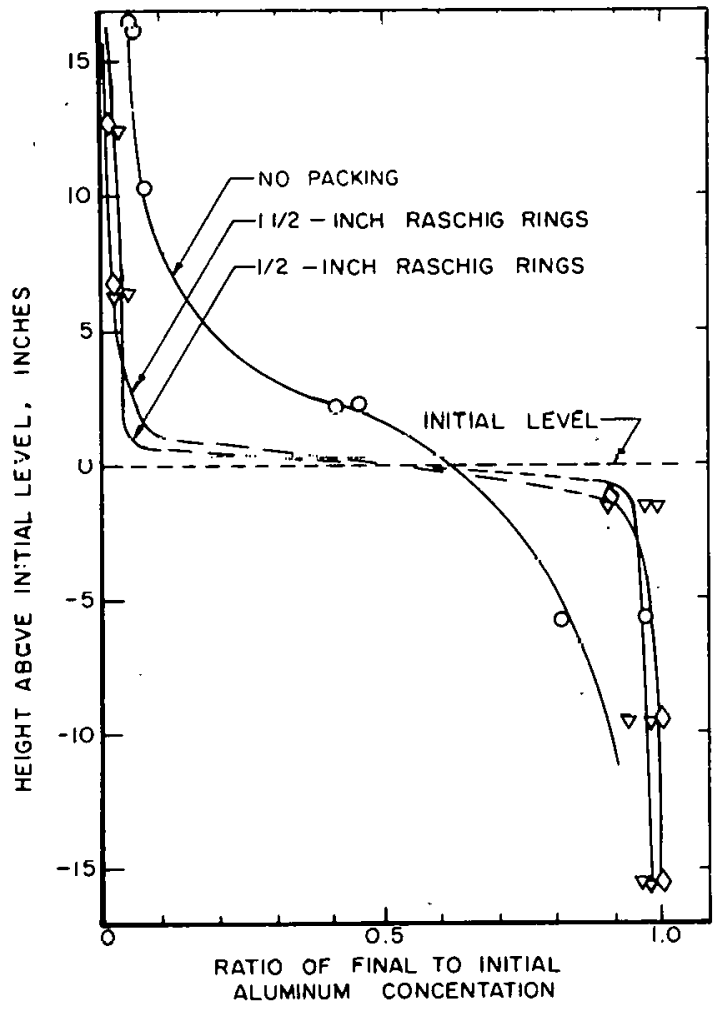

CPP-S -1795

Figure 16. Mixing Induced by Adding Water on Top of Concentrated. Aluminum Nitrate. (30" Diameter Tank, No Sparge Air, Sampled Immediately after the Initial Volume was Doubled).

Addition of Water to Aluminum Nitrate Solution

A series of tests similar to those previously discussed was made in which water was added to about 16 .inches of concentrated aluminum nitrate in the tank. These tests were also made with the unpacked tank and with the tank packed with the two sizes of Raschig ringe, the deta from these tests are plotted in Figure 16. This figure shows that if a less-dense solution is added to a more-dense solution in a tank with no packing, with $11 / 2$-inch Raschig rings, or with 1/2-inch Raschig rings, the resultant volume of solution is highly stratified immediately after the addition. It $c$ an be seen from Figure 16 that the copper-aluminum nitrate concentration transition zone between the two solutions in the unpacked tank is gradual, and in the tank with the 1/2-inch Raschig-ring packing the transition is abrupt. These data indicate that a tank must be sparged if a representative sample is to be obtained soon after the addition of a less-dense solution to a more-dense solution. 
Mixing Induced by Instrument Air

After the immediate sampling to establish the concentration zones between water and aluminum nitrate, respectively, in the top and bottom of the tank containing the 1 1/2-inch Raschig rings, the resulting mixture was allowed to remain in the tank for 18 hours to study the mixing caused by instrument air. During this period, the sparge air was off and each of the three submerged instrument probes was adjusted to its normal flow of 1 scfh of air which corresponds to a total of about 0.005 scfm of air per square foot of tank cross section. The density of the layer of aluminum nitrate solution in the bottom of the tank, as recorded by the instruments, changed from $1.32 \mathrm{~g} / \mathrm{cm}^{3}$ to $1.18 \mathrm{~g} / \mathrm{cm}^{3}$ in the first $21 / 2$ hours of this test. Fifteen hours later it had dropped to $1.17 \mathrm{~g} / \mathrm{cm}^{3}$, and it remained constant for the remainder of the test.

This test indicated that the stratification of solute in the tank was disrupted by the air from the instrument probes in $21 / 2$ hours. However, because it had a gradual change during the next 15 hours, it appeared that it was not homogeneous as defined by the standard of uniformity used in the previously-described air-sparge tests. Thus, the mixing caused by the instrument probes in a plant tank is believed to be minor relative to the mixing caused by a sparger. Although the diffusion of an electrolyte across a concentration gradient is inevitable, it is believed that diffusion had a negligible influence in these tests.

\section{DISCUSSION OF EVAPORATION TESTS}

The objectives of the evaporation tests were to determine if a packed evaporator could be operated satisfactorily and if the packing affected the heat transfer rate from jacket to solution. Samples were taken from many points in the body of the evaporating solution to measure concentration gradients.

\section{Investigation of the General Operability}

The packed evaporator operated satisfactorily at liquid levels between 10 and 36 inches and with a concentration range of from $0.1 \mathrm{M}$ to $3.0 \mathrm{M}$ aluminum nitrate. Since the tank contained 36 inches of packing an $\bar{d}$ 12 inches of free space above the packing, the freeboard may involve some packing. Operation with a liquid depth greater than 36 inches in the packed tank caused troublesome boilovers because the bubbles rose through the packing via more tortuous paths causing an expansion of the liquid to accomodate the greater ubble population. Excessive Iiquid levels when charging should be avoidable with adequate instrument alarms. Boilover was accentuated by the foaming experienced with concentrated aluminum nitrate solution. Although the sudden release of vapor due to superheating of the solution during start-up caused bollover during some evaporation tests, this was mitigated by sparging the solution during heating. Boilover also occurred during normal operation when 50 to 80 psig steam was used in the jackets together with a relatively high ( 35 - 37 inches) liquid level in the tank. The rise in liquid level due to an air-flow rate of up to one-tenth the flow rate of vapor 
formed at this operating rate was illustrated in Figure 13. Boilover was usually detected by a prolonged spurt of blue-colored, coppercontaining condensate and by a sharp drop in the evaporator liquid level.

The ICPP vessels are usually heated with low pressure steam; hence, the precaution of using low-pressure steam to prevent boilovers is automatically in effect. Boilover can be averted if about 0.6 scfm of air per square foot of tank cross section is used to induce circulation during start-up and if the solution depth is maintained with at least 12 inches of freeboard.

\section{Evaporation Rate Studies}

The effect of packing on the evaporation rate was studied while using the side and bottom heating jackets separately and together and while using the tank unpacked as well as packed. with the $11 / 2$-inch and 1/2-inch Raschig rings. These tests showed that the evaporation rates in a packed evaporator were comparable to those obtained in the unpacked evaporator.

The heat flux $(q / A)$ and, subsequently, the over-all heat transfer coefficient $\left(U_{0}\right)$ from the jacketed areas were calculated from the total volume of condensate collected during each interval and from the steamto-water temperature difference as measured by the steam pressure and by the thermocouple inside the tank. This temperature difference was corrected for the previously-discussed air cooling of the thermowell in the applicable cases. The convection and radiation losses were calculated on the bases of 24.2 square feet of unjacketed surface, a eurface-to-surroundings convection and radiation coefficient of $2.5 \mathrm{Btu} /(\mathrm{hr})\left(\mathrm{ft}^{2}\right)\left({ }^{\circ} \mathrm{F}\right)$, and an outside tank-surface temperature based on the temperature of the evaporating solution.

According to McAdams (10), boiling heat transfer data are frequently correlated in terms of the boiling film coefficient $\left(h_{f}\right)$ and of the temperature drop across the boiling film $\left(\Delta t_{f}\right)$, as follows,

$$
h_{f}=\frac{q / A}{\Delta t_{f}}=\frac{a\left(\Delta t_{f f}\right)^{n}}{\Delta t_{f}}
$$

where $a$ and $n$ are essentially constant in the limited range of $\Delta t_{f}$ being studied. With this relationship, groups of data having designed differences in variables can be tested by statistical methods to determine what efiects are significant. Since the presence of either the 1/2-inch or 1 1/2-inch Raschig-ring packing adjacent to the heat transfer surface could affect the value of $h_{f}$, a mathematical comparison of the data was desirable. It was not, however, possible to use equation (I) for this comparison because $\Delta t_{f}$ could not be measured directly or calculated. reliably. A calculated value of $\Delta t_{f}$ would be biased because of the sparge air around the thermowell and the heat conduction to the sparge ring through the tack weld. The previously mentioned difficulties in measuring the apparent condensate rate, caused by the platform scale-tank arrangement, would also adversely affect the calculated value of $\Delta t_{f}$. 
As an alternative method of evaluating these data and testing for the significant effects of various parameters, the data were fit to equations of the form:

$$
\mathrm{U}_{\mathrm{O}}=\mathrm{b}\left(\Delta \mathrm{t}_{\mathrm{O}}\right)^{\mathrm{m}}
$$

The relationship shown in Equation 2 is strictly true, however, only if $\triangle t_{f}$ and $\Delta t_{o}$ are linearly related. An analysis of some of the data showed this relationship is subject to an error of as much as 25 per cent. Nevertheless, it was felt that an error of this magnitude would not camouflage any truly significant effects of the variables being studied.

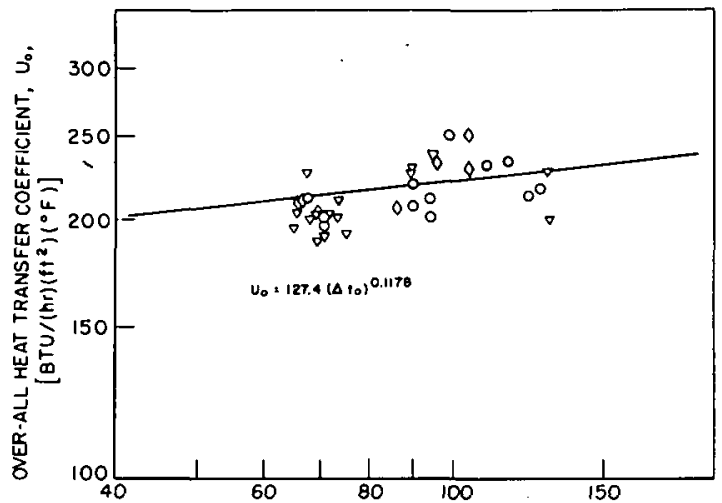

OVER-ALL TEMPERATURE DIFFERENCE, $\triangle t_{0},\left(^{\circ} \mathrm{F}\right)$ CPP-s-18s2

Figure 17. Over-all Heat Transfer Coefficient Using Both Jackets. Legend: $O$ No Packing; $\nabla 1$ 1/2-inch Rings; $\diamond 1 / 2$-inch Rings.

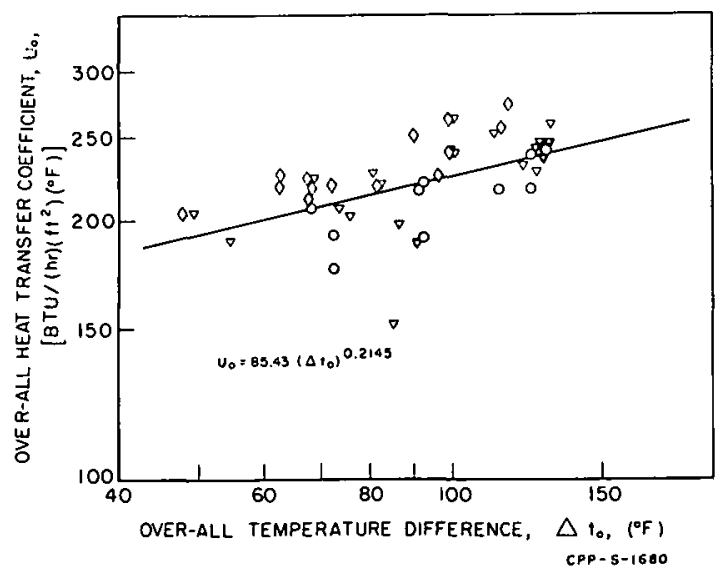

Figure 18. Over-all Heat Transfer Coefficient Using Side Jacket Alone. fer coefficients $\left(U_{0}\right.$ ) from the unpacked Legend: $\bigcirc$ No packing; $\nabla \quad I$ I/2-inch tank were slightly greater than the Rings; $\diamond 1 / 2$ inch Rings.
The over-all heat transfer coefficient obtained while using the side and bottom steam jackets together over a steam pressure range from 30 to 90 psig, are plotted in Figure 17 . Statistical tests on the data showed that solution-type and packing-type did not have a significant influence on the evaporation rate. Based on this finding, all the data common to the use of both jackets simultaneously were pooled and, by a regression analysis, represented by a single equation.

A series of tests was made to evaluate the effect of the side jacket alone on the heat transfer coefficient while using the two sizes of Raschig rings. These data, plotted in Figure 18, showed no significant effects of the variables of packing, solution type, or air-flow rate on the heat transfer coefficient $\left(U_{0}\right)$. A regression analysis of these data gave the best-fit equation for the points. Because the side jacket represents 81 per cent of the total jacket area, it is reasonable that this equation was only slightly different from the equation for the both-jacket data.

Another series of evaporation tests was made using the bottom jacket alone with water and aluminum nitrate over a steam-pressure range of 20 to 120 psig. These data are plotted in Figure 19. The regression analyses of these data and the tests for significance showed that the heat transtank were slightly greater than the packings were used. If the use of 


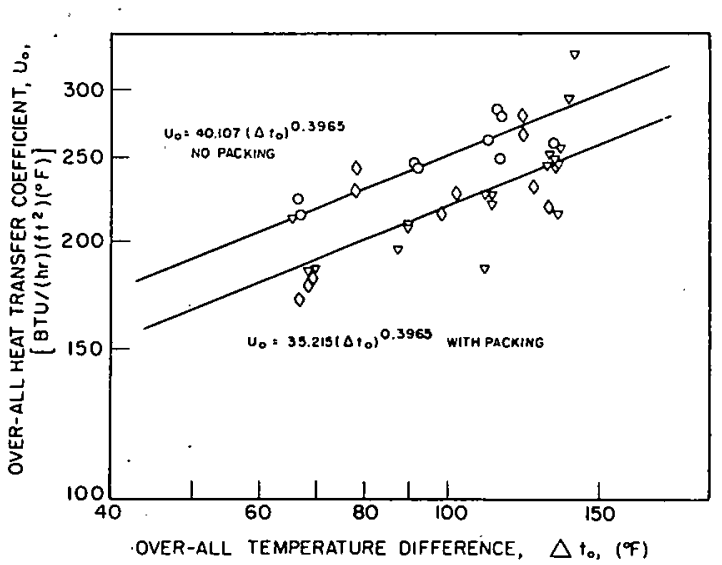

Figure 19. Over-all Heat Transfer Coefficient Using Bottom Jacke' Alone. Legend: $O$ No packing; $\nabla$ i $\overline{1} / 2$-inch Rings; $\Delta . \overline{1} / 2$-inch Rings. sparge air or the use of aluminum nitrate instead of water caused any small differences in the heat transfer rates, their effects were not statistically significant.

\section{Concentration Gradient Studies}

No significant concentration gradients were measured in the vessel during the evaporation studies. Table 1 gives the analyses of a typical set of samples taken during an evaporation. run. Although the absorbency of the samples varied slightly, this variation did not follow a trend attributable to the position of the sampling tubes relative to the side or the bottom of the tark.

Table 1

TYPICAL VARIATION OF COPPER CONCENTRATION

THROUGHOUT A VOLUME OF BOILING ALUMINUM NITRATE SOLUTION

\begin{tabular}{|c|c|c|c|c|c|c|}
\hline $\begin{array}{l}\text { Number of } \\
\text { Sample } \\
\text { Position }\end{array}$ & $\begin{array}{l}\text { Distance } \\
\text { of Sample } \\
\text { Tube From } \\
\text { Wall (in.) }\end{array}$ & $\begin{array}{r}\text { A } \\
\text { Terms } \\
8 " \\
\end{array}$ & $\begin{array}{c}\text { nalyses of Sample } \\
\text { of the Elevation } \\
16^{\prime \prime}\end{array}$ & $\begin{array}{l}\text { s Grouped } \\
\text { from the } \\
24 "\end{array}$ & $\begin{array}{l}\text { in } \\
\text { Bottom } \\
30^{\prime \prime} \\
\end{array}$ & $\begin{array}{c}\text { Group } \\
\text { Average }\end{array}$ \\
\hline $\begin{array}{r}1 \\
2 \\
7 \\
9 \\
14\end{array}$ & $\begin{array}{l}2 \\
2 \\
2 \\
2 \\
2\end{array}$ & $\begin{array}{l}0.257 \\
0.265\end{array}$ & 0.258 & 0.257 & 0.260 & 0.259 \\
\hline $\begin{array}{r}1 \\
8 \\
11 \\
12 \\
13\end{array}$ & $\begin{array}{l}7 \\
7 \\
7 \\
7 \\
7 \\
\end{array}$ & 0.260 & 0.256 & $\begin{array}{l}0.255 \\
0.250\end{array}$ & 0.263 & 0.257 \\
\hline $\begin{array}{r}3 \\
5 \\
6 \\
10 \\
15 \\
16\end{array}$ & $\begin{array}{l}11 \\
11 \\
11 \\
11 \\
11 \\
11\end{array}$ & 0.245 & $\begin{array}{l}0.258 \\
0.261\end{array}$ & 0.266 & $\begin{array}{l}0.254 \\
0.255\end{array}$ & 0.257 \\
\hline Group Avg. & & 0.257 & 0.258 & 0.257 & 0.258 & \\
\hline
\end{tabular}


The data in Table 2 show that the coefficient of variation throughout the boiling solution was slightly greater than the 0.3 to about 1.3 per cent coefficient of variation of the analytical method. However, the tracer concentration did not vary enough throughout the packing to regard either the packing type or the heating surface as having a significant effect on concentration uniformity.

Table 2

STANDARD DEVIATION OF SAMPLE ANALYSES UNDER VARIOUS EVAPORATION TEST CONDITIONS

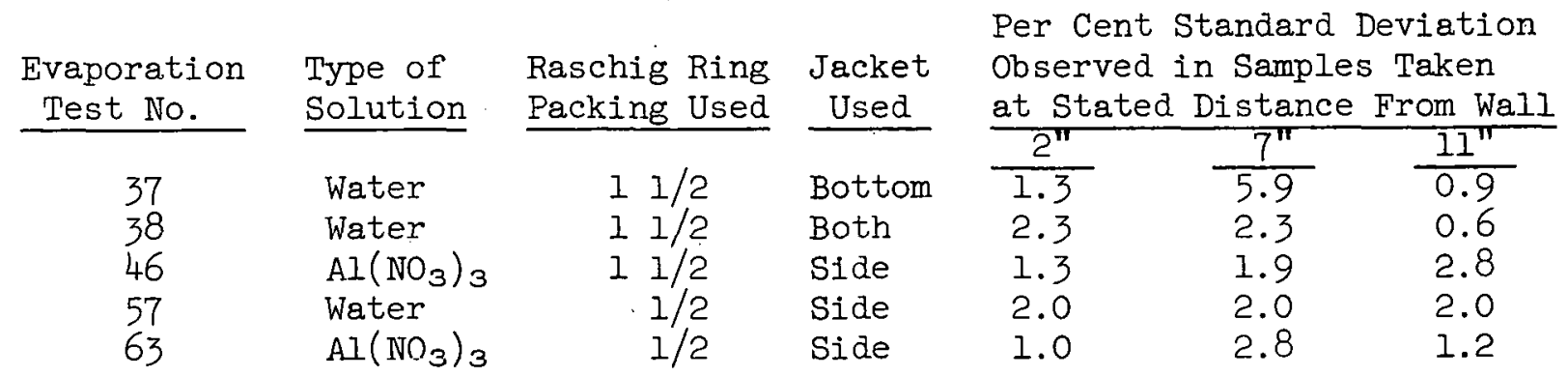

\section{CONCLUSIONS}

The principal result of this investigation was the proof that a tank packed with either 1 1/2- or 1/2-inch Raschig rings could be mixed by air. sparging from a distributor in the bottom of the tank and could operate satisfactorily as an evaporator.

The salient findings of the mixing studies were that the presence of the 1 1/2-inch Raschig rings caused a fourfold to tenfold increase in the time required for mixing as compared to the no-packing tests and that the presence of the 1/2-inch Raschig rings caused a 125- to 500-fold increase in the time required for mixing. The design of the air distributor, allowing tracer and packing to occupy a dead space between the distributor and the vessel, had an effect on the results that could not be isolated from the singular effect of either packing.

The main result obtained from the evaporation tests, aside from proving the system operated well, was an evaluation of the over-all heat transfer coefficients for the three vessel conditions: two with packing and one without packing. It was found that the use of the packing with the bottom jacket alone reduced the heat transfer coefficient slightly. However, in tests where the side jacket was used, there was no significant alfference betwcen the with- or without-jacket data, Neither were there any significant concentration gradients throughout the packing during an evaporation. 


\section{LITERATURE CITED}

(1) Bidinger, G. H., C. L. Schuske, and D. F. Smtth, RFP-201, Dow Chemical Company, Denver, Colorado (1960).

(2) Bryn, T., Forschung, 4, (1933). (Translated in David Taylor Model Basin Translation - 132, 1949.)

(3) Datta, R. L., D. H. Napier, and D. M. Newitt, Trans. Inst. Chem. Engr. (London), Advance copy, 14-26, February 14, 1950.

(4) Davidson, L., and E. H. Amick, Jr., A.I.Ch.E. Journal, 2, 337-342 (1956).

(5) Duncan, A. J., "Quality Control and Tndustrial Statistics," Richard D. Irwin; Inc., Daltimose, Ma. (1956).

(6) Fossett, H., Trans. Inst. Chem, Engr. (Toninn), 29, 322-332 (2951).

(7) Haberman, W. L., and R. K. Morton, Proc. A.S.C.E., 80, Separate No. $387(1954)$.

(8) Kauffman, H. L., Chem. and Met. Eng., 37, 178-180 (1930).

(9) Leibson, I., E. G. Holcomb, A. G. Cacoso, and J. J. Jacmic, A.I.Ch.E. Journal, 2, 300-306 (1956).

(10) McAdams, W. H., "Heat Transmission," Third Ed., McGraw-Hill Book Co., Inc., New Ynrk, N. Y. (195/I).

(11). Quigley, C. J., A. I. Johnson, and B. L. Harris, Chem. Eng. Prog. Symposium Ser. 51, No. 16, 31-45 (1955):

(12) Pattle, R. E'., Trans. Inst. Chem. Engr. (London), Advance sopy, 32-37, February 14, 1950.

(13) Peebles, F. N., and H. J. Garber, Chem. Eng. Prog., 49, 88-97 (1953).

(14) Verschoor, H., Trans. Inst. Chem. Engr. (London), Advance copy, 52.62, February 14, 1950 . 


\section{PHILLIPS}

PETROLEUM

COMPANY

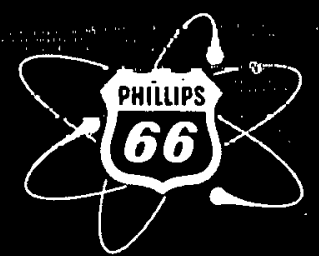

ATOMIC ENERGY DIVISION 